$11-1-1980$

\title{
State Income Taxation of Multijurisdictional Corporations: Reflections on Mobil, Exxon, and H.R. 5076
}

Walter Hellerstein

University of Georgia School of Law, wallyh@uga.edu

b bepress $S S R N$

\section{Repository Citation}

Walter Hellerstein, State Income Taxation of Multijurisdictional Corporations: Reflections on Mobil, Exxon, and H.R. 5076 (1980),

Available at: https://digitalcommons.law.uga.edu/fac_artchop/316

This Article is brought to you for free and open access by the Faculty Scholarship at Digital Commons @ University of Georgia School of Law. It has been accepted for inclusion in Scholarly Works by an authorized administrator of Digital Commons @ University of Georgia School of Law. Please share how you have benefited from this access For more information, please contact tstriepe@uga.edu. 


\title{
STATE INCOME TAXATION OF MULTIJURISDICTIONAL CORPORATIONS: REFLECTIONS ON MOBIL, EXXON, AND H.R. 5076
}

\author{
Walter Hellerstein*
}

The state tax field is enjoying a renaissance of sorts. The Supreme Court has displayed a renewed interest in the area, handing down an unusual number of significant decisions addressed to the constitutional restraints on state tax power.' State courts have exhibited a similar revival of interest in these problems through an outpouring of uncharacteristically thoughtful opinions concerning state taxation of multistate and multinational enterprise. ${ }^{2}$ Congress, whose concern with state taxation of interstate and foreign commerce has been sporadic, ${ }^{3}$ is again considering legislation that would

* Associate Professor of Law, University of Georgia; A.B. 1967, Harvard University; J.D. 1970, University of Chicago. - Ed. The author would like to thank Ellen R. Jordan and Michael Wells for their helpful comments on an earlier draft of this Article.

1. See, e.g., Japan Line, Ltd. v. County of Los Angeles, 441 U.S. 434 (1979) (announcing test for validity of state taxes on foreign commerce); United States Steel Corp. v. Multistate Tax Commn., 434 U.S. 452 (1978) (sustaining constitutionality of Multistate Tax Compact); Complete Auto Transit, Inc. v. Brady, 430 U.S. 274 (1977) (repudiating doctrine that states cannot tax the privilege of doing interstate business); Michelin Tire Corp. v. Wages, 423 U.S. 276 (1976) (establishing new analytical framework for determining validity of state taxes on imports). See generally W. Hellerstein, State Taxation and the Supreme Court: Toward a More Unified Approach to Constitutional Adjudication?, 75 MiCH. L. REv. 1426 (1977).

2. See, e.g., Qualls v. Montgomery Ward \& Co., 266 Ark. 207, 585 S.W.2d 18 (1979): Grace \& Co. v. Commissioner of Revenue, - Mass. - 393 N.E.2d 330 (1979); Budget RentA-Car of Wash.-Or., Inc. v. Multnomah County, 287 Or. 93, 597 P.2d 1232 (1979).

3. Prior to 1959 , Congress had not exercised its commerce power to legislate in the state tax field, although it had enacted legislation with respect to the power of the states to tax federal instrumentalities. See, e.g., Act of June 3, 1864, ch. 106, \& 41, 13 Stat. 111 (codified, as amended, at 12 U.S.C. $\S 548(1976)$ ). In 1959, Congress for the first time passed legislation limiting the power of the states to tax interstate commerce. See Act of Sept. 14, 1959, Pub. L. No. 86-272, 73 Stat. 555 (codified at 15 U.S.C. \$ 381 (1976)). See note 11 infra. Since 1959, Congress has enacted five additional pieces of legislation limiting state tax authority under its commerce power. In each case, the legislation was narrow in scope. See 15 U.S.C. \$391 (1976) (prohibiting states from imposing electrical energy taxes discriminating against out-ofstate purchasers); 15 U.S.C. $\$ 78 \mathrm{bb}(\mathrm{d})$ (1976) (prohibiting states from imposing stock transfer taxes when the only nexus between the state and the transaction is the presence of a transfer agent); 49 U.S.C. $\S 1513$ (1976) (prohibiting states from imposing user charges in connection with the carriage of persons in air commerce); 49 U.S.C. $\$ 11503$ (1978) (prohibiting states from taxing railroad property more heavily than other industrial and commercial property); Motor Carrier Act of 1980, Pub. L. No. 92-296, § 31, 94 Stat. 793 (to be codified at 49 U.S.C. $\$ 11503 a)$ (prohibiting states from taxing motor carrier property more heavily than other industrial and commercial property). Congress has from time to time held hearings on proposed legislation much broader in scope. See, e.g., Interstate Taxation, S. 2173: Hearings Before the 
limit state taxing authority in these domains. ${ }^{4}$ Even the executive branch, which seldom intervenes in state tax controversies that do not involve the federal government's own tax liability, has become embroiled in the broad conflict regarding the appropriate scope of state tax power. 5 The states, acting independently and through the Multistate Tax Commission, 6 have been intensifying their efforts to tax interstate and international business. ${ }^{7}$ And corporate taxpayers, whose dollars are ultimately the focus of all of this activity, have become increasingly vocal in seeking relief from state taxing schemes they regard as unduly burdensome. ${ }^{8}$

Senate Comm. on the Judiciary, 95th Cong., 1st \& 2d Sess. (1977-1978); State Taxation of Interstate Commerce: Hearings on State Taxation of Interstate Commerce Before the Subcomm. on State Taxation of Interstate Commerce of the Senate Comm. on Finance, 93d Cong., 1st Sess. (1973); Interstate Taxation Act: Hearings on H.R. 11798 Before the Special Subcomm. on State Taxation of Interstate Commerce of the House Comm. on the Judiciary, 89th Cong., 2d Sess. (1966). Bills growing out of these broader proposals were passed by the House in 1968, H.R. 2158, 90th Cong., 2d Sess., 114 CoNG. REC. 14,423 (1968), and in 1969, H.R. 7906, 91 st Cong., 1st Sess., 115 Cong. Rec. 17,315 (1969), but they died in the Senate. See 114 Cong. ReC. $14,432-33$ (1968) and 115 CONG. REC. 17,323 (1969).

4. H.R. 7163, 96th Cong., 2d Sess. (1980); H.R. 6654, 96th Cong., 2d Sess. (1980); H.R. 6625, 96th Cong., 2d Sess. (1980); H.R. 5076, 96th Cong., 1st Sess. (1979); S. 1778, 96th Cong., Ist Sess. (1979); S. 1688, 96th Cong., 1st Sess. (1979); S. 983, 96th Cong., 1st Sess. (1979). Hearings have been held on many of these proposals. Coal Severance Taxes: Hearings on H.R. 6625, H.R. 6654, and H.R. 7163 Before the Subcomm. on Energy and Power of the House Comm. on Interstate and Foreign Commerce, 96th Cong., 2d Sess. (1980); State Taxation of Foreign Source Income: Hearing on H.R. 5076 Before the House Comm. on Ways and Means, 96th Cong., 2d Sess. (1980) [hereinafter cited as House Foreign Source Income Hearingl; State Taxation of Interstate Commerce and Worldwide Corporate Income: Hearing on S. 983 and S. 1688 Before the Subcomm. on Taxation and Debt Management Generally of the Senate Comm. on Finance, 96th Cong., 2d Sess. (1980) [hereinafter cited as Senate Foreign Source Income Hearing].

5. See Japan Line, Ltd. v. County of Los Angeles, $441^{*}$ U.S. 434 (1979) (United States argued and filed brief as amicus curiae); House Foreign Source Income Hearing, supra note 4, at 3-11 (statement of Hon. Donald C. Lubick, Assistant Secretary of the Treasury for Tax Policy); Senate Foreign Source Income Hearing, supra note 4, 38-55 (statement of Hon. Donald C. Lubick, Assistant Secretary of the Treasury for Tax Policy); Tax Treaties with the Uniled Kingdom, the Republic of Korea, and the Republic of the Philippines: Hearings Before the Senate Comm. on Foreign Relations, 95th Cong., 1st Sess. 13-40 (1977) (statement of Hon. Laurence N. Woodworth, Assistant Secretary of the Treasury for Tax Policy) [hereinafter cited as Tax Treaty Hearings].

6. The Multistate Tax Commission is the administrative agency of the Multistate Tax Compact, whose purposes include the promotion of accuracy, equity, uniformity and convenience in the state tax treatment of multistate and multinational businesses. Multistate Tax Compact art. I, reproduced in [1980] 1 STATE TAX GUIDE (CCH) \351. There are presently 19 member states and 10 associate member states of the Compact. Id. The constitutionality of the Compact was sustained in United States Steel Corp. v. Multistate Tax Commn., 434 U.S. 452 (1978).

7. See Hansen, Business v. Nonbusiness Income of Large Multinational Corporations Under UDITPA, 57 TAXES 366 (1979); W. Hellerstein, Construing the Uniform Division of Income for Tax Purposes Act: Reflections on the Illinois Supreme Court's Reading of the "Throwback" Rule, 45 U. CHI. L. REv. 768 (1978); Scheele, State Taxation of Intangible Income of Multistate-Multinational Corporations, 57 TAXEs 678 (1979).

8. See House Foreign Source Income Hearing, supra note 4; Senate Foreign Source Income 
Congress has rarely limited state tax power; 9 existing limitations have been shaped largely by the Supreme Court. However, the Court's recent decisions have generally afforded states substantial leeway in taxing interstate business, ${ }^{10}$ and experience suggests that Congress can be persuaded to act in the climate created by such decisions. Congress enacted the most important piece of federal legislation restricting state tax authority as a direct response to a Supreme Court decision that allegedly construed state tax power so expansively as to cripple interstate business. " Moreover, the Court in its recent opinions has invited Congress to act if it is unhappy with the Court's hands-off attitude. ${ }^{12}$

The Court's two most recent decisions delineating the constitutional constraints on state taxation of interstate and foreign commerce should be viewed against this background. In Mobil Oil Corp. v. Commissioner of Taxes ${ }^{13}$ and Exxon Corp. v. Wisconsin Department of Revenue, ${ }^{14}$ the Court upheld state income taxes imposed on multistate and multinational corporations. The opinions reflect a generous view of state taxing authority. Because they explore a number of sensitive issues that have been brewing in the state courts and administrative agencies for years, the opinions are important in their own right. They assume additional importance because they

Hearing, supra note 4; Interstate Taxation: Hearings on S. 2173 Before the Senate Comm. on the Judiciary, 95th Cong., 1st \& 2d Sess. (1977-1978); Tax Treaty Hearings, supra note 5.

9. See note 3 supra.

10. See Moorman Mfg. Co. v. Bair, 437 U.S. 267 (1978); Washington Revenue Dept. v. Stevedoring Assn., 435 U.S. 734 (1978); National Geographic Socy. v. State Bd. of Equalization, 430 U.S. 551 (1977); Complete Auto Transit, Inc. v. Brady, 430 U.S. 274 (1977); Michelin Tire Corp. v. Wages, 423 U.S. 276 (1976). But see Japan Line, Ltd. v. County of Los Angeles, 441 U.S. 434 (1979); Boston Stock Exch. v. State Tax Commn., 429 U.S. 318 (1977).

11. Act of Sept. 14, 1959, Pub. L. 86-272, tit. I, $\S \S 101-104,73$ Stat. 555-56 (codified at 15 U.S.C. $\S \S 381-384$ ), was a specific response to the Supreme Court's decision in Northwestern States Portland Cement Co. v. Minnesota, 358 U.S. 450 (1959). Northwestern held that a state could constitutionally impose a nondiscriminatory, fairly apportioned net income tax upon a foreign corporation engaged exclusively in interstate commerce in the taxing state. A mere seven months after Northwestern, Congress enacted legislation establishing a minimum threshold of intrastate activities that must be exceeded by a foreign corporation in a state before that state may subject such a corporation to a tax measured by net income. 15 U.S.C. $\$ 381$ (1976). See generally Note, State Taxation of Interstate Commerce: Public Law 86-272, 46 VA. L. REv. 297 (1960). One of the other pieces of federal legislation limiting state tax authority under Congress's commerce power, see note 3 supra, was likewise a direct reaction to a Supreme Court decision. In Evansville-Vanderburgh Airport Auth. Dist. v. Delta Airlines, Inc., 405 U.S. 707 (1972), the Court upheld state enplaning charges as reasonable amounts charged to defray the costs of building or maintaining airport facilities used by the passengers. Congress responded by prohibiting the states from imposing user charges in connection with the carriage of persons in air commerce. 49 U.S.C. \& 1513 (1976).

12. See Moorman Mfg. Co. v. Bair, 437 U.S. 267, 280-81 (1978); Washington Revenue Dept. v. Stevedoring Assn., 435 U.S. 734, 749 (1978).

13. 445 U.S. 425 (1980).

14. 100 S. Ct. 2109 (1980). 
contribute to a climate that may lead Congress to take away from the states what the Court has apparently allowed them.

The purpose of this Article is twofold: first, to analyze the Mobil and Exxon decisions; second, to consider the congressional reaction they may engender. Because the terrain that this Article covers may be unfamiliar to some readers, a few further words of introduction may be appropriate.

Taken together, the Mobil and Exxon decisions dealt with the three methods of dividing a multijurisdictional corporation's income among the states - specific allocation, separate accounting and apportionment by formula. ${ }^{15}$ Each method provides a different solution to the problem of determining the portion of the income of multistate businesses that should be taxable by any one state.

Specific allocation traces income to the state of its putative single source and includes the income in that state's tax base. ${ }^{16}$ This method is employed principally for the attribution of income from property, with the "source" of the income generally following the location of the property. Thus, many states specifically allocate the income from real and tangible personal property, such as rents from real estate and oil and mineral royalties, to the state where the underlying property is located. ${ }^{17}$ With respect to income from intangible property, whose location for tax purposes may not be readily apparent, the states generally allocate the income to the taxpayer's commercial domicile ${ }^{18}$ or to the state in which the intangible is utilized. Thus, many states specifically allocate interest and dividend income to the state of the taxpayer's commercial domicile, ${ }^{19}$ while income from patents and copyrights may be allocated to the state where they are utilized. ${ }^{20}$

States have largely rejected specific allocation in the context of income from sales of interstate manufacturing and mercantile busi-

15. See, e.g., Special Subcomm. on State Taxation of Interstate Commerce of the House Comm. on the Judiciary, State TaXation of Interstate Commerce, H.R. Rep. No. 1480, 88th Cong., 2d Sess. 157-216 (1964). 1978).

16. See J. Hellerstein \& W. Hellerstein, State and Local Taxation 398 (4th ed.

17. See id. at 399, 490-91.

18. "Commercial domicile" is the state where a corporation's affairs are controlled and managed. See Wheeling Steel Corp. v. Fox, 298 U.S. 193, 211-12 (1936).

19. See UNIForm Division of Income for TAX PuRPoses ACT § 7. As of early 1981, more than half of the states levying corporate income taxes had in substance adopted the act. STATE AND Local TAXes (All States Unit) (P-H) I 1046 (1979).

20. See Uniform Division of Income for Tax Purposes Act § 8. See also note 19 supra. 
nesses, for several reasons. ${ }^{21}$ There are inherent difficulties in identifying the particular source of income generated by sales of multistate and multinational businesses. Consider, for example, the problem of determining the source of income generated by the sale of an item manufactured in State $A$, packaged and stored in State $B$, and sold in State $C$ by an enterprise managed in State $D$. The consequences of identifying such a source for purposes of specific allocation would be to assign much of the enterprise's income tax base to a single state despite legitimate claims by other states to a share of that tax base. As a result, the states have developed two alternative methods of determining the portion of a multistate business' net income that should be included in the measure of each state's tax: separate accounting and apportionment. ${ }^{22}$

Under the separate accounting method, a certain geographic or functional area of an interstate business is treated separately from the rest of the business. Income is computed as if the activities of the business were confined to that geographic or functional area. ${ }^{23}$ When income taxation of corporations began in this country, separate accounting for multistate operations was regarded as the most precise method of determining the income derived from various states. Under early state income tax laws, corporations were permitted to treat separately the income earned in each state as long as they maintained separate geographic accounting records that enabled them to ascertain that income with reasonable accuracy. ${ }^{24}$

Under the apportionment method, a formula is employed for dividing the income of a multistate business among the states in which the business is conducted. ${ }^{25}$ The rationale for using a formula for this purpose is that many enterprises conduct multistate businesses whose income cannot be satisfactorily identified on a geographic basis by either specific allocation or separate accounting. Because of this difficulty, states have developed apportionment formulas as a rough means of attributing a reasonable share of the income tax base of such a multistate business - referred to as a "unitary business" 26 - to the taxing state. ${ }^{27}$ The most widely adopted formula for attributing the income of a unitary business among states employs three

21. See J. Hellerstein \& W. Hellerstein, supra note 16, at 399.

22. See Keesling \& Warren, The Unitary Concept in the Allocation of Income, 12 HASTINGS L.J. 42, 43 (1960).

23. See id.

24. See J. Hellerstein \& W. Hellerstein, supra note 16, at 432.

25. See id. at 399.

26. For a definition of unitary business, see note 50 infra.

27. See J. Hellerstein \& W. Hellerstein, supra note 16, at 399-400; note 51 infra. 
factors: real and tangible personal property, payroll and sales. By averaging the ratios of the taxpayer's property, payroll and sales within the state to its property, payroll and sales throughout the business, the formula yields a fraction that can be applied to the taxpayer's net income to determine the portion taxable by the state.

In Mobil, an oil company challenged Vermont's reliance on formulary apportionment of income received by the company in the form of dividends from subsidiaries and affiliates doing business abroad. Mobil argued that, for tax purposes, the due process clause $^{28}$ and the commerce clause ${ }^{29}$ of the Constitution required that its foreign source dividend income be specifically allocated to the state of its commercial domicile, New York. The Court rejected Mobil's constitutional challenges. The Mobil decision recognized the power of the states to tax an apportioned share of the foreign source dividends of a unitary business but failed to delineate specific constitutional constraints on that power to ensure that such apportionments are fair.

In Exxon, an oil company relied on the due process clause and the commerce clause to challenge Wisconsin's formulary apportionment of all the company's operating income. Exxon argued that Wisconsin should apply a separate functional accounting method rather than apportionment and that it should include income only from Exxon's marketing activities - the sole function carried on in Wisconsin - in Exxon's tax base. The Court rejected Exxon's challenges in a decision that, like Mobil, defined state power expansively. Exxon implies that a state can tax an apportioned share of all the operating income of a business conducted in part within its borders as long as the apportionment formula is fair and the business is unitary. Yet, Exxon failed to define limits on the scope of a unitary business.

By broadly construing state tax authority without providing specific content to the constitutional restraints upon its exercise, the Court's opinions in Mobil and Exxon reflect a continuing attitude of judicial restraint in this area that has countenanced assertions of extensive taxing power by some states. California, for example, relies on the "worldwide combination" method to tax as a single unitary business numerous loosely connected corporations that are scattered around the globe. In the wake of Mobil, Exxon, and the increasing use of taxation methods like that employed by California, Congress

While the discussion in the text is addressed to apportionment of income, the underlying theory is applicable to apportionment of other tax bases as well. See id. at 397-99.

28. U.S. ConsT. amend. XIV, § 1.

29. U.S. Const. art. I, \& 8, cl. 3. 
may very well act to limit state taxation of the income of multijurisdictional corporations. Accordingly, after analyzing Mobil and Exxon, this Article examines H.R. 5076, a recent congressional proposal to limit state income taxation that has generated considerable interest and is supported in some quarters as a necessary antidote to these decisions.

\section{Mobil Oil Corp. v. Commissioner of Taxes: Constitutional Limitations on State TaXation of ForeigN SOURCE DIVIDENDS ${ }^{30}$}

Vermont imposes an income tax upon every corporation doing business in the state, ${ }^{31}$ including the Mobil Oil Corporation. Mobil is the world's third largest integrated oil company ${ }^{32}$ and does business in more than forty states and in many foreign countries. Mobil's worldwide activities include the exploration, production, transportation, refining, distribution, and sale of petroleum and petroleum products. In foreign countries, Mobil acts largely through wholly and partly owned subsidiaries and affiliates, some of which are incorporated abroad and some of which are incorporated domestically in states other than Vermont. None of these subsidiaries or affiliates conducts business in Vermont, and Mobil manages its holdings in these corporations from its headquarters in New York, its state of incorporation. Mobil's activities in Vermont are limited to the wholesale and retail marketing of petroleum and petroleum products. ${ }^{33}$

Under the constraints of the commerce and due process clauses, Vermont may tax only the portion of a corporation's income that is fairly related to activities carried on by the corporation within the state. ${ }^{34}$ Vermont uses the apportionment method to tax the income of corporations like Mobil, which derive income from "business or activity conducted both within and without th[e] state."35 To appor-

30. In accordance with the Michigan Law Review's policy of indicating any personal interest, however remote, that an author had in litigation he discusses in an article, I wish to discloșe that my father, Jerome $\mathrm{R}$. Hellerstein, was counsel of record in the Mobil case and that I was of counsel to the Iowa Manufacturers Association, et al., which submitted a brief amici curiae supporting the state in Moorman Mfg. Co. v. Bair, 437 U.S. 267 (1978), discussed in text at notes 113-29, 180-83, and 194-204 infra.

31. Vt. Stat. ANN. tit. 32, $\S 5811(15), 5832$ (1970 \& Supp. 1979).

32. See Fortune Magazine, Aug. 11, 1980, at 190. Mobil was also the nation's third largest industrial corporation in 1979. Id., May 5, 1980, at 276.

33. 445 U.S. at 428.

34. See, e.g., Moorman Mfg. Co. v. Bair, 437 U.S. 267 (1978).

35. VT. STAT. ANN. tit. 32, § 5833 (1970 \& Supp. 1979). 
tion a "fair and equitable portion"36 of the income, Vermont employs the three-factor formula of property, payroll and sales. ${ }^{37}$ The state applies the fraction ${ }^{38}$ yielded by the formula to the taxpayer's federal taxable income (with minor modifications ${ }^{39}$ ) to determine the portion of the income taxable by Vermont.

The dispute between Mobil and Vermont centered on the question whether Vermont was constitutionally entitled to include within Mobil's tax base, before apportionment, dividends that Mobil received from its subsidiaries and affiliates whose income derived from foreign sources. ${ }^{40}$ Mobil claimed that the inclusion of these dividends in its apportionable tax base was prohibited by the due process and commerce clauses and by established federal policy toward foreign commerce. The Vermont Supreme Court had rejected these contentions and sustained Vermont's power to impose an apportioned tax upon income that included foreign source dividends received by a corporation domiciled outside Vermont. ${ }^{41}$

The stakes in the case were high, at least in relative terms. Mobil's foreign source dividend income ranged from 80 to $120 \%$ of its federal taxable income for the years in question. ${ }^{42}$ The exclusion of such income from Mobil's apportionable tax base for Vermont tax purposes had the effect of transforming substantial net income into net losses for two of the three years at issue and into a small gain for the third. ${ }^{43}$ Moreover, there was intense interest outside of Mobil's Tax Department and the Vermont Attorney General's Office over the question whether a nondomiciliary state possesses the constitutional power to include in its apportionable tax base foreign source dividends received by an American corporation doing business in

36. VT. Stat. ANn. tit. 32, § 5833 (1970 \& Supp. 1979).

37. VT. Stat. ANN. tit. 32, § 5833 (1970 \& Supp. 1979); see State and Local Taxes (All States Unit) (P-H) \ 1046 (1980).

38. Vt. Stat. ANN. tit. 32, § 5833 (1970 \& Supp. 1979).

39. Modifications include the exclusion of income exempt from state taxation under federal law, see, e.g., 31 U.S.C. $\$ 742$ (1976), and the exclusion of "grossed-up dividends" required to be taken into taxable income in connection with the foreign tax credit. I.R.C. $\$ 78$. See VT. Stat. ANn. tit. 32, §5811(18) (Supp. 1980).

40. These included dividends both from United States corporations earning their income abroad, to the extent that such dividends were not eliminated from Mobil's federal taxable income by the intercorporate dividend deduction, see I.R.C. $\$ \$ 243-47$, and from foreign corporations earning their income abroad.

41. Mobil Oil Corp. v. Commissioner of Taxes, 136 Vt. 545, 394 A.2d 1147 (1978). Neither Mobil's legal domicile (the state of its incorporation) nor its commercial domicile (the state where its affairs are controlled and managed, see note 18 supra) was in Vermont.

42. See 445 U.S. at 430.

43. 445 U.S. at $430-31$ n.6. 
the state. ${ }^{44}$

The Supreme Court upheld the levy.45 While the Court's holding may be "extremely narrow" and "unexceptional," as Justice Stevens characterized it in dissent, ${ }^{46}$ Mobil nevertheless resolved several issues that had long divided taxpayers and state taxing authorities, and it has unmistakable implications for others that are a source of continuing controyersy. As a result, this "unexceptional" case may encourage a far-reaching congressional response.

\section{A. Due Process Clause Limitations on State Taxation of Foreign Source Dividends}

The due process clause imposes two restrictions on the states' power to tax income generated by the activities of an interstate business. First, there must be "some minimal connection between those activities and the taxing State." 47 Second, "the income attributed to the State for tax purposes must be rationally related to 'values connected with the taxing State" "48 — that is, the state may tax only the portion of a multistate corporation's income that is rationally related to the activities that the corporation conducts in that state.

For Vermont to include Mobil's foreign source dividend income in its tax base, therefore, the first due process restriction required a minimum connection, or nexus, between Vermont and the activities that generated the dividends. That nexus was not obvious. Mobil's subsidiary and affiliate corporations, which paid the dividends, conducted none of their business in Vermont. And all of Mobil's activities relating to its stock holdings in these corporations, including the receipt and management of the dividends themselves, also occurred outside Vermont. ${ }^{49}$

Vermont relied on the unitary business principle for its minimum

44. The large number of amicus briefs filed in the Supreme Court by both state and business spokesmen attest to the outside interest in the case. Twenty states, represented in part by the Multistate Tax Commission, see note 6 supra, supported Vermont as amici curiae. The National Association of Manufacturers and the Committee on State Taxation of the Council of State Chambers of Commerce supported Mobil as amici curiae. Standard Oil of California filed an amicus brief supporting the State.

45. 445 U.S. 425 (1980).

46. 445 U.S. at 449,450 .

47. Moorman Mfg. Co. v. Bair, 437 U.S. 267, 273 (1978). The Court had earlier referred to this requirement as the "time-honored concept . . that due process requires some definite link, some minimum connection, between a state and the person, property, or transaction it seeks to tax." Miller Bros. v. Maryland, 347 U.S. 340-45 (1954).

48. Moorman Mfg. Co. v. Bair, 437 U.S. 267, 273 (1978). (1980).

49. Brief for Appellant at 9, Mobil Oil Corp. v. Commissioner of Taxes, 445 U.S. 425 
connection to Mobil's foreign source dividends. ${ }^{50}$ According to this principle, when a multijurisdictional unitary business is doing business within a state, that state has the required nexus to both the instate and out-of-state activities of the business, and is therefore entitled to $\operatorname{tax}$ an apportioned share of all its income. ${ }^{51}$ Vermont claimed that all the foreign source dividends at issue came from Mobil's stockholdings in subsidiaries and affiliates that constituted integral parts of a worldwide unitary business carried on in part in Vermont.52 Furthermore, Vermont asserted that its power to include all the income of the unitary business within Mobil's apportionable tax base was not limited by the multinational, multicorporate form in which the business was conducted, or by the form in which the income was received. ${ }^{53}$ Vermont argued that Mobil's foreign source dividends were therefore an element of its unitary business income and that the state was entitled to tax an apportioned share.

Mobil claimed that the due process clause forbade Vermont from including Mobil's foreign source dividends in its apportionable tax base because the minimum connection between Vermont and Mobil's foreign source dividends was lacking. Mobil agreed that the unitary business principle can establish a taxing state's connection to the out-of-state activities of corporations other than the corporate taxpayer where all the corporations form a unitary business, and that such a connection justifies the state's including income generated by

50. A unitary business may be defined as a single business conducted both within and without the taxing state and whose tax base cannot be satisfactorily identified on a geographical basis. See G. Altman \& F. Keesling, Allocation of Income in State Taxation 101 (2d ed. 1950).

51. See G. Altman \& F. KeEsling, supra note 50, at 100-02. The states resorted to apportionment formulas because of the impracticability or impossibility of identifying the tax base of a unitary business along geographic lines. See text at notes 25-27 supra. The Supreme Court has generally approved of formulary apportionment as a rough means of attributing a reasonable share of the tax base to the taxing state. See, e.g., Underwood Typewriter Co. v. Chamberlain, 254 U.S. 113, 120-21 (1920). The question whether a particular business is unitary (and its tax base apportionable) has often been a source of controversy, see, e.g., Bass, Ratcliff \& Gretton, Ltd. v. State Tax Commn., 266 U.S. 271 (1924); Adams Express Co. v. Ohio State Auditor, 165 U.S. 194 (1897), and delineation of the proper scope of a unitary business has been the subject of scholarly commentary. See, e.g., G. Altman \& F. KEesLino supra; J. Hellerstein, Recent Developments in State Tax Apportionment and the Circumscription of Unitary Business, 21 NATL. TAX. J. 487 (1968); Keesling \& Warren, supra note 22; Lavelle, What Constitutes a Unitary Business, 25 S. CAL. TAx INsT. 239 (1973); Rudolph, State Taxation of Interstate Business: The Unitary Business Concept and Affiliated Corporate Groups, 25 TAX L. REv. 171 (1970); Comment, State Taxation of Multinational Corporations, 50 Colo. L. REV. 499 (1979); Note, State Taxation of Unitary Businesses, 8 FoRD URB. L.J. 819 (1980); see also note 7 supra. The constitutional contours of the unitary business are explored in more detail in connection with the Exxon case, discussed in part II infra. (1980):

52. Brief for Appellee at 16, Mobil Oil Corp. v. Commissioner of Taxes, 445 U.S. 425

53. Id. at 17 . 
the entire multicorporate enterprise in the apportionable tax base. ${ }^{54}$ The company asserted, however, that if the unitary business principle is the predicate for the connection, then the multicorporate enterprise must be taxed on a combined (or "consolidated") basis. 55 Under this approach, ${ }^{56}$ the tax base before apportionment consists of the combined or consolidated income of all the corporations that comprise the unitary business. ${ }^{57}$ The property, payroll, sales or other factors of all the corporations are taken into account in apportioning to a state the share of the group's combined income subject to that state's taxing power. ${ }^{58}$ Mobil argued that unless Vermont had taxed Mobil on such a basis, the State could not rely on the unitary business principle to establish its minimum connection tó Mobil's foreign source dividends.

Mobil showed that Vermont had not taxed it using a combined approach. Under the combined approach, the apportionable income of a group of corporations conducting a unitary business is the income derived by members of the multicorporate unitary enterprise from dealings with nonmembers of the group. ${ }^{59}$ Dividends paid by one member of the group to other members are eliminated altogether from the tax base. If Vermont had treated Mobil in this manner, the controversy between them would never have arisen because the intercorporate dividends at issue would not have been a component of Mobil's apportionable tax base. Vermont, however, had taxed an apportioned share of Mobil's intercorporate dividends. Thus, Vermont had not taxed Mobil on a combined (or "consolidated") basis, and, according to Mobil, Vermont consequently had failed to treat Mobil as a unitary business - or more precisely, had not done so in an analytically defensible manner. ${ }^{60}$

Instead, Vermont had taxed Mobil according to a separate company apportionment. Under this method, the taxing state takes into account only the income of the taxpayer itself and only the taxpayer's own apportionment factors. ${ }^{61}$ Vermont had taxed an apportioned share of the dividends received from subsidiaries and

54. Reply Brief for Appellant at 2-3, Mobil Oil Corp. v. Commissioner of Taxes, 445 U.S. 425 (1980).

55. Id. at 2-5, 10-12.

56. See generally J. Hellerstein \& W. HelleRstein, supra note 16, at 520-26.

57. See Keesling \& Warren, supra note 22, at 59-64; Rudolph, supra note 51, at 194-200.

58. See Keesling \& Warren, supra note 22, at 59-64; Rudolph, supra note 51, at 194-200.

59. See Keesling \& Warren, supra note 22, at 59-64; Rudolph, supra note 51, at 194-200.

60. Reply Brief for Appellant at 1-15, Mobil Oil Corp. v. Commissioner of Taxes, 445 U.S. 425 (1980).

61. Id. at 3. 
affiliates as income earned by Mobil as a separate company; the State did not include the income earned by these subsidiaries and affiliates in Mobil's tax base. Likewise, Vermont had apportioned Mobil's income on the basis of the property, payroll and sales of Mobil alone as a separate company, without taking into account the factors of its subsidiaries and affiliates.

In essence, Mobil argued that Vermont could not treat the company and its subsidiaries and affiliates as a unitary business for purposes of establishing the nexus for taxation of foreign source income, while at the same time treating the company as separate for purposes of apportionment. Because Vermont had treated it as a separate company, Mobil asserted that Vermont's power under the due process clause to include the disputed dividends in Mobil's apportionable tax base required that Vermont demonstrate its nexus to Mobil's activities and operations as a separate company, ${ }^{62}$ rather than as part of a unitary business conducted in multicorporate form. Mobil argued that Vermont lacked this nexus with respect to Mobil's activities involving its foreign source dividends because Mobil held the stocks and received the dividends outside Vermont, and there was no link or connection between Vermont and the earnings out of which the dividends were paid. ${ }^{63}$

The Supreme Court never had to address the question whether Vermont had the requisite nexus to Mobil's foreign source dividends by reference solely to Mobil's activities as a separate company. ${ }^{64}$ The Court found that Mobil had not pressed in a timely manner its claim premised on the distinction between separate and combined apportionment.65 It therefore permitted Vermont to rely on the unitary business principle to establish its nexus to Mobil's foreign source dividends even though Vermont had apportioned Mobil's income on a separate company basis. It left open the question whether a state that relies on the unitary business principle to justify its inclu-

62. Id. at 3-6.

63. Brief for Appellant at 9 and Appendix to the Court's opinion at A83, Mobil Oil Corp. v. Commissioner of Taxes, 445 U.S. 425 (1980).

64. Even if the Court had addressed the issues according to Mobil's formulation, it might have found the necessary relationship between Mobil, viewed as a separate company, and its subsidiaries and affiliates, to justify the inclusion of dividends from these corporations in Mobil's apportionable Vermont tax base - on the ground, for example, that the dividends were used to finance Mobil's sales operations in Vermont. The question whether such a relationship should warrant the inclusion of dividends in the payee's apportionable tax base is itself a subject of heated controversy. See Dexter, Taxation of Income from Intangibles of MultistateMultinational Corporations, 29 VAND. L. REV. 401 (1976).

65. 445 U.S. at $441 \mathrm{n} .15$. The Court also observed there that the record was, in any event, inadequate to dispose of these contentions. 
sion in the apportionable tax base of income generated by a multicorporate enterprise will be compelled to tax that enterprise on a combined basis. 66

As the Court approached the case, then, Vermont's power to include Mobil's foreign source dividends in the company's apportionable tax base turned on the question whether such dividends constituted income from a worldwide unitary business conducted in part in Vermont. Observing that "the linchpin of apportionability in the field of state income taxation is the unitary business principle,"67 the Court declared that Mobil had to demonstrate that its foreign source dividend income "was earned in the course of activities unrelated to the sale of petroleum products in [Vermont]" 68 to establish that such income was not subject to an apportioned tax in the state. Since Mobil had claimed that Vermont could not apply the unitary business principle because the State had never treated Mobil as a unitary business, Mobil had presumed that it was irrelevant whether the subsidiaries and affiliates from which it received foreign source dividends were in fact part of a unitary enterprise. ${ }^{69}$ As a result, it never sought to prove that its subsidiaries and affiliates were not part of a unitary business: ${ }^{70}$

[A]ppellant has made no effort to demonstrate that the foreign operations of its subsidiaries and affiliates are distinct in any business or economic sense from its petroleum sales in Vermont. Indeed, all indications in the record are to the contrary, since it appears that these foreign activities are part of appellant's integrated petroleum enterprise. In the absence of any proof of discrete business enterprise, Vermont was entitled to conclude that the dividend income's foreign source did not destroy the requisite nexus with in-state activities. ${ }^{71}$

The Court reviewed the evidence Mobil had offered to prove a lack of connection (on a separate company basis) between Vermont and Mobil's activities involving its foreign source dividends. The Court found that this evidence failed to show that Mobil's activities involving these dividends constituted a business discrete from its sale of petroleum in Vermont. In the Court's view, the fact that Mobil received substantial income in the form of dividends did not require Vermont to treat Mobil as conducting a separate holding company

66. 445 U.S. at 441 n.15.

67. 445 U.S. at 439 (footnote omitted).

68. 445 U.S. at 439.

69. Reply Brief for Appellant at 1-2, Mobil Oil Corp. v. Commissioner of Taxes, 445 U.S. 425 (1980).

70. 445 U.S. at 435; Reply Brief for Appellant at 4-5, Mobil Oil Corp. v. Commissioner of Taxes, 445 U.S. 425 (1980).

71. 445 U.S. at $439-40$. 
and investment business outside the state" in the face of "the underlying economic realities of a unitary business."73 Nor was the foreign source of the dividend income of significance for due process purposes. The Court had long held that the states could include foreign source operating income in their apportionable tax base, ${ }^{74}$ and it perceived no reason for a different result with respect to foreign source dividend income, at least absent a showing that the business activities of the payor corporations were unrelated to the in-state activities of the payee. ${ }^{75}$ Under the Court's analysis, then, Mobil's due process contention failed for want of proof.

Even if viewed exclusively in this light, the Mobil decision is significant in establishing that the due process clause does not preclude a state from including foreign source dividend income from subsidiaries and affiliates in the apportionable tax base of a nondomiciliary ${ }^{76}$ corporation. ${ }^{77}$ The multicorporate form of a business will not by itself shield income distributed as dividends from state taxation if such income is derived from a unitary business. ${ }^{78}$ The taxpayer must

72. See Brief for Appellant at 9, Mobil Oil Corp. v. Commissioner of Taxes, 445 U.S. 425 (1980).

73. 445 U.S. at 441 .

74. Bass, Ratcliff \& Gretton, Ltd. v. State Tax Commn., 266 U.S. 271 (1924). In Bass, the taxpayer was engaged in the brewing and sale of ale. All of the brewing was done in England, but the taxpayer sold some of its products in New York, which sought to impose a franchise tax upon the corporation, measured by an apportioned share of its worldwide net income. The taxpayer challenged the New York levy on due process and commerce clause grounds, claiming, among other things, that because it had no net income for federal tax purposes, New York was necessarily taxing income from business conducted outside the state. The Court responded:

[A]s the Company carried on the unitary business of manufacturing and selling ale, in which its profits were earned by a series of transactions beginning with the manufacture in England and ending in sales in New York and other places - the process of manufacturing resulting in no profit until it ends in sales - the State was justified in attributing to New York a just proportion of the profits earned by the Company from such unitary business.

266 U.S. at 282.

75. 445 U.S. at 439.

76. Mobil was domiciled in New York and not Vermont. See note 41 supra.

77. For a discussion of the battle lines that were drawn over this proposition, see Dexter, supra note 64.

78. The Court specifically addressed the intercorporate division of Mobil's unitary business:

Superficially, intercorporate division might appear to be a more attractive basis for limiting apportionability. But the form of business organization may have nothing to do with the underlying unity or diversity of business enterprise. Had appellant chosen to operate its foreign subsidiaries as separate divisions of a legally as well as a functionally integrated enterprise, there is little doubt that the income derived from those divisions would meet due process requirements for apportionability. Transforming the same income into dividends from legally separate entities works no change in the underlying economic realities of a unitary business, and accordingly it ought not to affect the apportionability of income the parent receives.

445 U.S. at 440-4I (citation and footnote omitted). 
demonstrate that economic substance underlies the formal distinctions between separate corporate entities. Only if the income-generating activities of the payor corporations are "unrelated" to, 79 "discrete" from, 80 or "have nothing to do with" 81 the activities of the payee in the taxing state - that is, only in the absence of a unitary business - does the due process clause require the state to exclude from the payee's apportionable tax base dividends received from the payor.

The Court failed, however, to address the second due process restriction on the states' power to tax income generated by the activities of an interstate business - the requirement of a rational relationship between the income taxed and the in-state corporate activities. As a result, serious doubts remain whether the income attributed to Vermont by its apportionment formula was "rationally related to "values connected with the taxing state.' "82 The first unresolved issue is whether due process requires that a state, relying on the unitary business principle to include income generated by a multicorporate enterprise in the apportionable tax base, must apportion that income according to the combined approach, ${ }^{83}$ or whether the separate company approach may also be employed. ${ }^{84}$ Assuming for the moment that the due process clause permits Vermont to tax an apportioned share of the dividend income Mobil receives from its subsidiary and affiliate corporations (the separate company approach), ${ }^{85}$ the particular apportionment formula Vermont used would still violate the clause's rational relation requirement. Vermont sought to meet this requirement by providing for apportionment of a share of Mobil's income pursuant to its three-factor formula. 86 The Supreme Court has approved of that formula "as a rough, practical approximation of the distribution of either a corporation's sources of income or the social costs which it generates."87 But the Court's remarks were directed to cases in which the factors - real and tangible personal property, payroll and sales - were rationally related to the operating income of the taxable corpora-

79. 445 U.S. at $439,442$.

80. 445 U.S. at 439.

81. 445 U.S. at 442.

82. Moorman Mfg. Co. v. Bair, 437 U.S. 267, 273 (1978).

83. This is what Mobil contended, see text at note 56 supra.

84. This was the approach that Vermont employed. See text at notes 59-60 supra.

85. Again, Vermont employed this approach in the case before the Court.

86. VT. STat. ANN. tit. 32, § 5833 (1970 \& Supp. 1979). See text at notes 20-22 supra.

87. General Motors Corp. v. District of Columbia, 380 U.S. 553, 561 (1965). 
tion. ${ }^{88}$ By contrast, Vermont was applying its formula to income that, in form at least, derived from Mobil's investments in its subsidiaries and affiliates, not from its operations. When a corporation receives between 80 and $120 \%$ of its taxable income from intangible property, it is anomalous - and perhaps grossly distorting ${ }^{89}$ - to apportion such income by a formula that, among other things, takes no account of intangible property. ${ }^{90}$ As Justice Stevens observed in dissent:

Clearly, it is improper simply to lump huge quantities of investment income that have no special connection with the taxpayer's operations in the taxing State into the tax base and to apportion it on the basis of factors that are used to allocate operating income.91

While Vermont, in assessing Mobil's tax liability, was not constitutionally compelled to honor the form in which Mobil chose to conduct its business, the state should not be permitted to have it both ways: to include in Mobil's apportionable tax base income from its subsidiaries and affiliates operating abroad but to apportion such income by factors reflecting only Mobil's own operations on a separate company basis. Therefore, Vermont must adjust the apportionment factors to comply with the due process requirement that the income apportioned be "rationally related to "values connected with the taxing State." "92

To make this adjustment, Vermont might employ an apportionment formula whose factors reflect the underlying business activities of the dividend-paying corporations. ${ }^{93}$ For example, if a corporation pays out all of its net income in dividends to the corporate taxpayer, then all of the payor's property, payroll and sales would be included as apportionment factors to apportion the taxpayer's income to the state. On the other hand, if a corporation pays out only fifty percent of its net income in dividends to the corporate taxpayer, then only fifty percent of the payor's property, payroll and sales would be reflected in the payee's apportionment factors. ${ }^{94}$ In either case, assum-

88. See General Motors Corp. v. District of Columbia, 380 U.S. 553, 561 (1965); Butler Bros. v. McColgan, 315 U.S. 501, 509 (1942).

89. See Rudolph, supra note 51, at 203. Cf. F.W. Woolworth Co. v. Director of Div. of Taxation, 45 N.J. 466, 494-99, 213 A.2d 1, 17-19 (1965) (application of three-factor formula to tax base that includes receipts from foreign subsidiaries held to comply with due process, but case remanded for consideration of adjustments to apportionment factors that would make apportionment more equitable).

90. See J. Hellerstein \& W. Hellerstein, supra note 16, at 455-56.

91. 445 U.S. at 459 (footnote omitted).

92. Moorman Mfg. Co. v. Bair, 437 U.S. 267, 273 (1978).

93. See Peters, Sup. Ct's Mobil decision on multistate income apportionment raises new questions, 53 J. TAX. 36, 39 (1980).

94. Id. 
ing that the payor corporation carries on little or no activity in the taxing state, taking account of the payor corporation's operations increases the denominators of the apportionment formula and reduces the percentage of the taxpayer's income apportioned to the state..$^{95}$ Alternatively, Vermont might apply a special formula to the dividend income that reflects only the activities of the payee corporation relating to the management and disposal of its dividends. ${ }^{96}$

These proposed adjustments to Vermont's separate company apportionment presuppose that a state can first invoke the unitary business principle to include income generated by a multicorporate enterprise in its apportionable tax base, and then apportion that income on a separate company basis. The issue remains, however, whether a state that thus invokes the unitary business principle to satisfy the nexus requirement may apportion the income on a separate company basis or whether, to avoid the distortion of income, the rational relationship requirement of due process demands that the income and apportionment factors of the entire unitary business be taken into account under a combined approach. In general, a state may tax an apportioned share of all the income of a unitary business. The Court in Mobil permitted Vermont to employ the separate company approach, and to include in Mobil's apportionable tax base the dividends from Mobil's subsidiaries and affiliates, because the dividends reflected the income that the subsidiaries and affiliates earned as integral parts of the unitary business and because the income of the subsidiaries and affiliates was not taxed directly.97 Adjusting Vermont's apportionment factors to reflect the business activities of the dividend-paying corporations would tighten the connection between the income and the dividends of the subsidiaries and affiliates, and therefore a separate company approach that included such adjustments may be a constitutionally acceptable alternative to the combined approach. But the dividends may still not accurately reflect the operating income of the payor corporations. ${ }^{98}$ Consequently, the combined approach, which includes the subsidiaries' and affiliates' operating income in the apportionable tax base and then apportions such income by factors that reflect the underlying

95. Cf. Mobil Oil Corp. v. Commissioner of Taxes, 445 U.S. 425,441 n.15 (1980) (combined apportionment also increases the denominator and reduces the percentage of the taxpayer's income apportioned to the state).

96. See Peters, supra note 93, at 39. This adjustment to Vermont's apportionment formula might satisfy Justice Stevens's objections. See 445 U.S. at 449 (Stevens, J., dissenting).

97. 445 U.S. at 440.

98. Additional problems exist if the dividends are paid out of prior years' earnings or capital. Peters, supra note 93, at 39. 
operations of the subsidiaries and affiliates, is more justifiable analytically.

For the time being, however, the constitutional status of the combined and separate company approaches remains unresolved. We are left with an opinion explicitly confined "to the question whether there is something about the character of income earned from investments in affiliates and subsidiaries operating abroad that precludes, as a constitutional matter, state taxation of that income by the apportionment method";99 and to a holding on the due process issue explicitly limited to the proposition that, on the record before it, such income "is attributable to the parent and amenable to fair apportionment."100 It remains unclear whether the Court's refusal to confront arguments premised on the distinction between separate and combined apportionment truly reflects a misguided "litigation strategy" 101 by Mobil (the company saved these arguments for its reply brief $^{102}$ ), or rather the understandable reluctance of the Court to become entangled in the complex and controversial web of issues they raised.103 By refusing to consider whether the resulting apportionment was in fact fair and whether the combined approach or some other modification in the apportionment formula would be required to make it fair, the Court relegated to a footnote ${ }^{104}$ a constitutional issue far more troublesome than the one it resolved.

\section{B. Commerce Clause Limitations on State Taxation of Foreign Source Dividends}

The commerce clause provided Mobil with a constitutional defense to Vermont's tax on its foreign source dividends that was distinct from its due process defense. ${ }^{105}$ One of the limitations that the Court has developed in delineating the restraints that the commerce clause imposes on state tax power is the doctrine that a state tax unconstitutionally burdens interstate commerce when it subjects an interstate business to multiple taxation not borne by an intrastate

99. 445 U.S. at 434-35.

100. 445 U.S. at 441 n.15.

101. 445 U.S. at 434.

102. See 445 U.S. at 441 n.15.

103. See generally authorities cited in notes 7,51 \& 77 supra.

104. 445 U.S. at 441 n. 15.

105. The commerce and due process clauses frequently provide alternative but substantively indistinguishable bases for challenging the constitutionality of state apportionment formulas. See, e.g., Norfolk \& W. Ry. v. Missouri State Tax Commn., 390 U.S. 317, 325 n.5 (1968). 
business. ${ }^{106}$ Mobil constructed a chain of interrelated propositions to show that Vermont had violated this principle in taxing its foreign source dividends. The company argued, first, that the state of its commercial domicile ${ }^{107}$ had the power to tax all of its dividends; second, that the possible exercise of this power together with Vermont's taxation of an apportioned share of Mobil's foreign source dividends created the risk of multiple taxation; third, that this risk was the criterion for determining whether Vermont's tax violated the commerce clause's bar against multiple taxation; fourth, that even if a risk of multiple taxation is constitutionally tolerable when only taxation of interstate commerce is involved, it may be unconstitutional when it involves taxation of foreign commerce; and finally, that Vermont's power to tax even an apportioned share of Mobil's foreign source dividends created such an intolerable risk. ${ }^{108}$ While Mobil's somewhat attenuated commerce clause argument lacked the force of its due process challenge, the Court's opinion rejecting it is nonetheless significant for illuminating a number of controversial issues.

\section{Multiple Taxation: Potential or Actual?}

The Court first addressed the question whether the Vermont levy imposed an unconstitutional burden on interstate commerce by subjecting Mobil to a risk of multiple taxation not borne by a taxpayer conducting all of its business within a single state. ${ }^{109}$ Vermont's claim to an apportioned share of Mobil's dividends threatened to expose more than $100 \%$ of Mobil's tax base to state taxation because of the asserted power of New York, the state of Mobil's commercial domicile, to tax all of Mobil's dividends on an unapportioned basis. Since New York did not in fact tax the dividends at issue, Mobil was subjected only to a risk of multiple taxation, and the Court felt that it was appropriate to consider initially whether proof of actual - not merely potential - multiple taxation is a prerequisite to establishing a violation of the commerce clause. 110

The Court removed some of the uncertainty that has shrouded

106. See, e.g. 445 U.S. at $442-46$.

107. See note 41 supra. (1980).

108. Brief for Appellant at 14-37, Mobil Oil Corp. v. Commissioner of Taxes, 445 U.S. 425

109. See 445 U.S. at $442-44$.

110. Because the Court ultimately concluded that the commercial domicile lacked the power to tax Mobil's dividends on an unapportioned basis, see text following note 129 infra, the Court might have avoided reaching this issue by assuming arguendo that the risk test applied. 
this issue ${ }^{111}$ by rejecting the contention that actual multiple taxation must always be demonstrated to make out a case under the commerce clause. The Court agreed with Mobil "that the constitutionality of a Vermont tax should not depend on the vagaries of New York tax policy."112 The Court thus put its imprimatur upon the "risk" theory of the multiple taxation doctrine.

We should not be too quick to conclude, however, that Mobil represents a sweeping endorsement of the risk theory. Just two years earlier in Moorman Manufacturing Co. v. Bair, ${ }^{113}$ the Court took a different approach in rejecting a commerce clause challenge to a state apportionment formula. Moorman, a manufacturer and seller of animal feeds, manufactured in Illinois all of its products sold to Iowa customers. It sought to demonstrate that Iowa's single-factor sales formula for apportioning net income, in conjunction with Illinois's standard three-factor formula, subjected income derived from its Iowa sales to duplicative taxation in violation of the commerce clause. 114 The Court rejected this claim on two grounds. First, Moorman had failed to establish the "essential factual predicate"115 for a claim of duplicative taxation: the company had not proven that "Illinois and Iowa together imposed a tax on more than 100\% of the relevant net income." 116 Second, despite this flaw in the taxpayer's case, the Court went on to address the constitutional issues raised by the two conflicting formulas on the assumption that they produced "some overlap" 117 in the taxation of Moorman's income. The Court then repudiated Moorman's contention that the commerce clause prohibits any overlap in the computation of taxable income by the states, taking the position that the risk of duplicative taxation does not automatically offend the commerce clause. ${ }^{118}$

111. See, e.g., W. Hellerstein, supra note 7, at 799-803.

112. 445 U.S. at 444.

113. 437 U.S. 267 (1978).

114. Iowa's single-factor formula consisted of the ratio of Moorman's gross sales in the state to the company's entire gross sales, wherever located. This ratio was applied to Moorman's net income to determine the amount of its income taxable by lowa. 437 U.S. at 270 . By contrast, Illinois used three factors to determine the portion of Moorman's income it could tax: Moorman's real and tangible personal property, payrolls and sales. For each factor Illinois compared the amount of the factor in lllinois to the amount occurring everywhere. The three ratios were then averaged and the resulting fraction applied to Moorman's net income. Because the two states employed different factors, there was a risk of duplication in the taxable income calculated by each state. See 437 U.S. at 277. For an illustration of duplicative taxation resulting from inconsistent apportionment formulas, see note 123 infra.

115. 437 U.S. at 276.

116. 437 U.S. at 276.

117. 437 U.S. at 277.

118. If the Constitution were read to mandate such precision in interstate taxation, the consequences would extend far beyond this particular case. For some risk of duplicative 
Given the different approaches to the multiple taxation doctrine in Mobil and Moorman, the question arises whether they are consistent. It is possible, of course, that Mobil simply overrules sub silentio Moorman's insistence on proof of actual duplicative taxation for establishing a commerce clause claim predicated on the multiple taxation doctrine. Indeed, the obvious distinction between the cases, that Mobil but not Moorman involved foreign commerce, provides no basis for reconciling them because the Court in Mobil accepted the risk theory of multiple taxation without taking into account the alleged presence of foreign commerce. ${ }^{119}$ Nevertheless, there is a basis for reconciling the opinions. The risk deemed sufficient by the Court in Mobil to raise a constitutional issue was created by two theoretically inconsistent methods of attributing income to a state for tax purposes: specific allocation of all Mobil's foreign source dividends to a single situs - Mobil's commercial domicile, New York - versus apportionment of the dividends by formula among Vermont and other states. ${ }^{120}$ If the two methods were employed simultaneously by different states, they would necessarily cause multiple taxation. In Moorman, by contrast, the dispute was not over the method of attributing income to a state; the parties were in agreement that apportionment by formula was the appropriate method of determining the share of Moorman's income that Iowa might constitutionally tax. Rather, the dispute was over the choice of the particular formula employed by the State. The Court may be prepared to police the choice of division-of-income rules insofar as is necessary to prevent the states from adopting different methods of division that will, if applied, necessarily result in duplicative taxation. It may not, however, be willing to engage in the "extensive judicial lawmaking" 121 of prescribing the precise formula that a state must adopt in dividing

taxation exists whenever the States in which a corporation does business do not follow identical rules for the division of income. . . . The asserted constitutional flaw in th[e] formula is that it is different from that presently employed by a majority of States and that difference creates a risk of duplicative taxation. But a host of other division-of-income problems create precisely the same risk and would similarly rise to constitutional proportions.

Thus, it would be necessary for this Court to prescribe a uniform [apportionment] formula [for all the states] . . . . The Constitution, however, is neutral with respect to the content of any uniform rule.

437 U.S. at $278-79$.

119. See 445 U.S. at $443-44$. The Court addressed foreign commerce only in a separate portion of the opinion, and treated it merely as an additional consideration. See 445 U.S. at $446-49$.

120. See text at notes 16-27 supra for a more extensive discussion of allocation and apportionment.

121. Moorman, 437 U.S. at 278. 
income by the apportionment method. ${ }^{122}$

This explanation may be questioned on two grounds. First, it places substantial and, perhaps, unwarranted weight on the distinction between duplicative taxation caused by the adoption of two different methods of attributing income and duplicative taxation caused by the adoption of two variations on a single method. The multiple taxation resulting from the application of two inconsistent variations of a particular method is no less inevitable and burdensome than the multiple taxation resulting from the application of methods that are themselves inconsistent. ${ }^{123}$ It would be odd for a Court committed to deciding state tax cases on the basis of "the practical effect of the exaction" 124 to enshrine as a principle of constitutional analysis a distinction based on whether duplicative taxation resulted from inconsistency between, rather than within, methods of income attribution. Second, the Court in Moorman directed its comments to multiple taxation problems created by inconsistent divisionof-income rules without regard to whether the problems were caused by inter- or intra-methodological inconsistencies. Although the case was limited to a choice between apportionment formulas, the Court explicitly adverted to risks of multiple taxation that were created by choices between allocation to the commercial domicile, on the one hand, and apportionment by formula, on the other. ${ }^{125}$

The Court may ultimately resolve the apparent conflict between Mobil and Moorman over whether an actual burden must be shown to establish a case of multiple taxation. ${ }^{126}$ For the moment, Mobil and Moorman lay the groundwork for future controversies regarding this issue. The Court's approach in Mobil is more principled than its

122. Some support for this thesis may be found in the Court's long-standing and frequently repeated view that "rough approximation rather than precision" is the constitutional standard for judging the validity of apportionment formulas, see, e.g., International Harvester Co. v. Evatt, 329 U.S. 416, 422 (1947) (quoting Illinois Cent. Ry. v. Minnesota, 309 U.S. 157, 161 (1940)), and its recognition that "apportionment necessarily entails some inaccuracy and duplication." Mobil, 445 U.S. at 446 (citing the rationale in Japan Line, Lid. v. County of Los Angeles, 441 U.S. 434 (1979)).

123. For example, if all of an enterprise's property is located in State $A$, which has a singlefactor property formula for apportioning income, and all of the enterprise's sales are made in State $B$, which has a single-factor sales formula for apportioning income, the resulting duplicative taxation is as inexorable and onerous as any that may be produced by a conflict between two different methods of income attribution.

124. Washington Revenue Dept. v. Stevedoring Assn., 435 U.S. 734, 750 (1978).

125. 437 U.S. at $278-79 \&$ n. 15 .

126. The Court again faced this issue in Exxon Corp. v. Wisconsin Dept. of Revenue, 100 S. Ct. 2109 (1980), argued even before the Court decided Mobil. But the commerce clause claims in the two cases were so similar, and the Court in Exxon followed its reasoning in Mobil so exactly, that Exxon sheds little additional light on the issue. See text at notes 229-33 infra. 
approach in Moorman and meets the objection that limitations on state taxing power should not be on a "first-come-first-tax basis."127 Nevertheless, consideration of the appropriate judicial role in reviewing state apportionment formulas, as well as the suspicion that undertaxation rather than overtaxation of multistate corporate income is the norm, ${ }^{128}$ warns against an unreserved embrace of the risk criterion. Until the issue is resolved, only a taxpayer that demonstrates that more than $100 \%$ of its income has in fact been subjected to state taxation can depend on the Court to grant relief. ${ }^{129}$

\section{Taxation of Dividend Income: Allocation or Apportionment?}

Having determined that alleging a risk of multiple taxation provided Mobil with a basis for challenging the Vermont levy under the commerce clause, the Court turned to the question whether the risk in fact existed. The answer depended on whether New York, the state of Mobil's commercial domicile, possessed the power to tax all of Mobil's dividends. If, as Mobil argued, New York possessed such power, then Vermont's power to tax even an apportioned share of those dividends created a risk of multiple taxation. Because these two methods of income attribution - specific allocation to a single state and apportionment among the states - together produced a risk of multiple taxation, the Court was forced to choose between them.

Faced with this choice, the Court had little hesitation in concluding that apportionment was the appropriate method of determining which states are entitled to tax a corporation's dividend income. It traced the allocation of dividends to a single situs to cases involving taxation of intangible property, where allocation served to avoid multiple taxation of ownership. ${ }^{130}$ It observed that the doctrinal basis for such an allocation - mobilia sequunter personam ${ }^{131}$ - had

127. General Motors Corp. v. Washington, 377 U.S. 436, 458 (1964) (Goldberg, J., dissenting).

128. We should soon be in a better position to determine whether this suspicion is warranted. See text at note 277 infra.

129. This conclusion finds support in the Court's emphasis in Moorman that the taxpayer's claim was "speculative," 437 U.S. at 276, 280, as well as the Court's observations in Mobil that the presence or absence of an actual burden does alter the nature of a taxpayer's claim, 445 U.S. at 444 , and that the Court possesses the power to correct gross overreaching resulting from apportionment. 445 U.S. at 447 . Even this conclusion may be challenged, however. Moorman can be read together with the Court's unwillingness to constitutionalize state division-of-income rules or to prescribe uniform national standards for attributing income to the states to suggest that even an actual burden will not raise a commerce clause claim when the burden results from inconsistency in such rules. See 437 U.S. at 278-80.

130. 445 U.S. at 445.

131. Movables follow the person. 
been discredited as "stat[ing] a rule without disclosing the reasons for it." 132 It noted further that the rule of allocation to a single situs had not only been eroded in the context of property and franchise taxes, ${ }^{133}$ but that it had no necessary application to income from intangibles. ${ }^{134}$ While recognizing New York's power to impose some tax on Mobil's dividend income, the Court concluded:

There is no reason in theory why that power should be exclusive when the dividends reflect income from a unitary business, part of which is conducted in other States. In that situation, the income bears relation to benefits and privileges conferred by several states. These are the circumstances in which apportionment is ordinarily the accepted method. Since Vermont seeks to tax income, not ownership, we hold that its interest in taxing a proportionate share of appellant's dividend income is not overridden by any interest of the state of commercial domicile. ${ }^{135}$

Three points place this conclusion in proper perspective. First, the commerce clause portion of the Mobil opinion did not answer the questions left open by the Court's due process holding. In neither part of the decision did the Court hold that the apportionment of Mobil's dividend income by a formula reflecting Mobil's own operations, but not those of its subsidiaries and affiliates, was necessarily defensible. Instead, it held only that Vermont was entitled to tax an apportioned share of Mobil's dividends. The commerce clause, like the due process clause, ${ }^{136}$ requires that a state income tax be fairly apportioned. ${ }^{137}$ But in the commerce clause portion of the opinion, as in the due process portion, the fairness of Vermont's method was not addressed by the Court because Mobil, in the Court's view, had not challenged it. ${ }^{138}$ Second, the Court's approval of apportionment rather than allocation in this case does not mean that allocation is inappropriate in all contexts. Here the disputed dividends arose out of activities that were deemed to be part of a unitary business, ${ }^{139}$ and the Court limited its holding to such dividends. Dividends that do not reflect activities of a taxpayer's unitary

132. 445 U.S. at 445 (quoting First Bank Stock Corp. v. Minnesota, 301 U.S. 234, 241 (1937)).

133. 445 U.S. at 445 (citing Ford Motor Co. v. Beauchamp, 308 U.S. 331 (1939); Curry v. McCanless, 307 U.S. 357 (1939); Adams Express Co. v. Ohio State Auditor, 166 U.S. 185 (1897)).

134. 445 U.S. at 445 (citing Wheeling Steel Corp. v. Fox, 298 U.S. 193 (1936)).

135. 445 U.S. at $445-46$.

136. See text at note 48 supra.

137. See 445 U.S. at 443 (quoting Complete Auto Transit, Inc. v. Brady, 430 U.S. 274, 279 (1977)).

138. 445 U.S. at 434,449 . See text at notes $66,82-104$ supra.

139. 445 U.S. at 442 . See text at notes $47-75$ supra. 
business in a taxing state will presumably be excluded from the state's apportionable tax base and either apportioned to states where the dividends reflect another unitary business of the taxpayer, or, perhaps, allocated to the taxpayer's commercial domicile if the dividends are from true portfolio investments. ${ }^{140}$ Finally, the Court's preference for apportionment among the states over allocation to a single state is by no means limited to state income taxes. Indeed, the Court's modern decisions involving property taxes reflect a similar preference. ${ }^{141}$

\section{Taxation of Dividend Income from Foreign Source: Allocation or Apportionment?}

The Court's preference for apportionment over allocation of dividend income did not dispose of Mobil's commerce clause claim. Mobil argued that however matters might stand if the controversy concerned dividends from domestic sources, dividends from foreign sources were entitled to additional constitutional protection that could be provided only by allocating them to the state of commercial domicile. ${ }^{142}$ Mobil's argument relied heavily on Japan Line, Ltd. $v$. County of Los Angeles, ${ }^{143}$ which struck down a local property tax on Japanese cargo containers whose full value had already been taxed in Japan. The Court held that a state lacks power under the commerce clause to impose even a fairly apportioned, nondiscriminatory property tax upon foreign-owned and foreign-based instrumentalities of foreign commerce used exclusively in furtherance of such commerce. Japan Line identified two factors (beyond those the Court ordinarily considers in adjudicating the validity of state taxes on interstate commerce) that must be considered when a state seeks

140. See UNIForm Division of INCOME for TAX PuRPoses Act (U.L.A.) $\$ \S 1(a), 1(e), 4$ 7. Intangibles have sometimes been found to acquire a taxable "business situs," distinct from the taxpayer's commercial domicile, when they have become an integral part of the taxpayer's business carried on in a state. See, e.g., First Bank Stock Corp. v. Minnesota, 301 U.S. 234, 237 (1937); Wheeling Steel Corp. v. Fox, 298 U.S. 193, 208-10 (1936); New Orleans v. Stempel, 175 U.S. 309, 322-23 (1899). The Court's rejection of these property tax concepts as analogies for taxation of income from intangibles, 445 U.S. at 445 , coupled with its preference for apportionment rather than allocation of income integrally related to some part of the taxpayer's business, 445 U.S. at $445-48$, suggests that the Court would not view the "business situs" of intangibles as an alternative to the commercial domicile for allocating dividend income unrelated to the taxpayer's business in the taxing states. It would instead view such income as apportionable by those states, including the "business situs," in which the taxpayer conducted a unitary business to which such dividends related.

141. See Japan Line, Ltd. v. County of Los Angeles, 441 U.S. 434, $441-44$ (1979).

142. Brief for Appellant at 14-16, 22-37, Mobil Oil Corp. v. Commissioner of Taxes, 445 U.S. 425 (1980).

143. 441 U.S. 434 (1979). 
to tax instrumentalities of foreign commerce: 144 "the enhanced risk of multiple taxation," 145 . and the possibility that "a state tax on the instrumentalities of foreign commerce may impair federal uniformity in an area where federal uniformity is essential."146 Mobil urged that these considerations justified a rule allocating dividends from foreign sources to a company's commercial domicile.

The Court found the analogy to Japan Line "forced"147 and "unpersuasive."148 First, Japan Line involved property taxation, and the Court had already expressed reservations about applying reasoning from property tax cases to division-of-income problems. ${ }^{149}$ Second, Japan Line involved multiple taxation at the international level, whereas Mobil, which had conceded the power of the state of its commercial domicile to tax $100 \%$ of its foreign source dividends, was ultimately concerned solely with multiple taxation among the states. ${ }^{150}$ Even though such multiple taxation might burden foreign commerce, the ability to remove the burden lay within the Court's power, since it enjoyed final authority over the reach of state taxing measures. In Japan Line, by contrast, where the problem involved duplicative taxation by a state and a foreign sovereign, the Court lacked the "ability to enforce full apportionment by all potential taxing bodies,"15I and it therefore felt compelled to deny Los Angeles - as it would, presumably, any other American political subdivision - the power to tax the Japanese containers at all. ${ }^{152}$ Finally, the Court defended its refusal to adopt a rule of allocation for foreign source dividends by warning of its implications. ${ }^{153}$ Because Mobil's argument was not logically confined to dividend income, it could well be applied to other types of foreign source income. Such an extension would cause significant difficulties for state tax authorities in trying to determine the foreign source of particular items of in-

144. When foreign commerce is not involved, a tax on interstate commerce will withstand constitutional scrutiny under the commerce clause if it "is applied to an activity with a substantial nexus with the taxing state, is fairly apportioned, does not discriminate against interstate commerce, and is fairly related to the services provided by the State." E.g., Complete Auto Transit, Inc. v. Brady, 430 U.S. 274, 279 (1977).

145. 441 U.S. at $446-48$.

146. 441 U.S. at $448-51$.

147. 445 U.S. at 448.

148. 445 U.S. at 446.

149. 445 U.S. at 448. See text at notes 130-34 supra.

150. 445 U.S. at 447-48.

151. Japan Line, Ltd. v. County of Los Angeles, 441 U.S. at 447.

152. 441 U.S. at 447-48.

153. Mobil Oil Corp. v. Commissioner of Taxes, 445 U.S. at 447. 
come, ${ }^{154}$ a task that is obviated when an apportionment scheme is employed. This reasoning suggests that in the appropriate case the Court would likewise conclude that other kinds of foreign source income from intangibles - such as foreign source interest, royalty, and patent income - may be apportioned rather than allocated. ${ }^{155}$

\section{Federal Tax Policy and State Taxation of Foreign Source Dividends}

The second factor identified in Japan Line as bearing on the application of the commerce clause to state taxation of foreign commerce - the danger that such taxation will "preven[t] the Federal Government from 'speaking with one voice when regulating commercial relations with foreign governments' "156 — laid the groundwork for Mobil's final claim, a claim based on federal preemption. Mobil argued that established federal policies of avoiding double taxation of foreign source income and encouraging the payment of foreign dividends required that the state of a corporation's commercial domicile alone be empowered to tax foreign source dividends. ${ }^{157}$ The Court gave short shrift to this argument:

The federal statutes and treaties that Mobil cites ... concern problems of multiple taxation at the international level and simply are not germane to the issue of multiple state taxation that appellant has framed. Concurrent federal and state taxation of income, of course, is a well-established norm. Absent some explicit directive from Congress, we cannot infer that treatment of foreign income at the federal level mandates identical treatment by the States. ${ }^{158}$

The Court's disposition of this issue would not, under most circumstances, merit attention. The Court has seldom found in federal tax or related policy any basis for limiting state taxation of private enterprise, ${ }^{159}$ and there was nothing about Mobil's case that seemed likely to produce an exception to the general rule. What makes the Court's remarks significant, however, is that they may have a bearing on proposed congressional restrictions on state taxation of foreign

154. 445 U.S. at 447.

155. The Court offered one additional reason for distinguishing Japan Line. It observed that Japan Line involved actual multiple taxation that could be relieved only by allocation to the commercial domicile, Japan, whereas no duplicative taxation was actually involved in $\mathrm{Mo}$ bil. 445 U.S. at 448 . The Court's reliance on this distinction is inconsistent with its view, expressed earlier in the opinion, that the risk rather than the fact of multiple taxation was the controlling constitutional criterion. See text at note 112 supra.

156. 441 U.S. at 451 (quoting Michelin Tire Corp. v. Wages, 423 U.S. 276, 285 (1976)).

157. Brief for Appellant at 38-48, Mobil Oil Corp. v. Commissioner of Taxes, 445 U.S. 425 (1980).

158. 445 U.S. at 448.

159. A rare exception is McGoldrick v. Gulf Oil Corp., 309 U.S. 414 (1940). 
source income. The proposed legislation in large part imposes upon the states the federal model for taxing foreign source income. If the Court's observation that "problems of multiple taxation at the international level . . . simply are not germane to the issue of multiple state taxation" 160 is relevant not only to constitutional adjudication but also to sound tax policy, then the congressional effort may be fundamentally misdirected.

Part III of this Article will explore this problem as well as others raised by the Congress's proposed limitations of state taxation of foreign source income - a debate that will now proceed in the shadow of Mobil. But an informed discussion of the proposed legislation first requires an understanding of the Exxon decision.

\section{EXXON CORP. v. Wisconsin DEPARTMENT OF REVENUE: State TaXation OF a UNITARY Business}

The Court's decision in Exxon Corp. v. Wisconsin Department of Revenue ${ }^{161}$ followed on the heels of Mobil. ${ }^{162}$ Although the issues in Exxon and Mobil were distinguishable, it would have been hard to write an opinion delineating the constitutional constraints on state taxation of one integrated oil company without affecting a subsequent opinion addressed to such constraints on state taxation of another oil company. Indeed, while Exxon possesses independent significance, the principles set forth in Mobil substantially influenced the analysis in Exxon, notwithstanding Exxon's last-minute effort to bring to the Court's attention the "pronounced and readily discernible differences"163 between the two cases.

Like Vermont, Wisconsin imposes an income tax upon every corporation doing business in the state. ${ }^{164}$ Like Mobil, Exxon is one of the world's largest integrated oil companies. ${ }^{165}$ Like Mobil, Exxon conducted its integrated operations from wellhead to gas pump on a global basis, yet its activities in Wisconsin, like Mobil's in Vermont, were limited to the marketing of petroleum products. Unlike the

160. 445 U.S. at 448.

161. 100 S. Ct. 2109 (1980).

162. Mobil was decided on March 19, 1980, the day after oral argument in Exxon. Exxon was decided on June 10, 1980.

163. Supplemental Brief for Appellant at 7, Exxon Corp. v. Wisconsin Dept. of Revenue, 100 S. Ct. 2109 (1980).

164. Wis. STAT. $\S 871.01(1),(2)$ (1977).

165. In fact, based on sales, it is the largest, and it was also the nation's largest industrial corporation in 1979. See Fortune MAGazINE, Aug. 11, 1980, at 190; id., May 5, 1980, at 276. Exxon is the legal successor to Humble Oil and Refining Co., the original taxpayer during the years in question, 1965-1968. $100 \mathrm{~S}$. Ct. at 2113-14 n.1. This Article will follow the Court's opinion in referring to the taxpayer by its present name. $100 \mathrm{~S}$. Ct. at 2114 n.1. 
controversy between Mobil and Vermont, however, the controversy between Exxon and Wisconsin did not concern dividend income. Indeed, during the years in question Wisconsin did not seek to include dividend income received by a nondomiciliary corporation like Exxon within the corporation's apportionable tax base. ${ }^{166}$ Rather, the dispute was over operating income. Specifically, Exxon challenged the constitutionality of Wisconsin's application of its three-factor apportionment formula ${ }^{167}$ to all of the company's operating income even though the company carried on only marketing activities in Wisconsin and had segregated, by separate functional accounting, the income produced by its marketing activities from its out-of-state, nonmarketing activities. As in Mobil, the Court rejected both Exxon's due process and commerce clause arguments.

\section{A. Due Process Limitations on State Taxation of a Unitary Business}

\section{Separate Accounting versus Formulary Apportionment}

The main thrust of Exxon's due process argument was that it had done what Mobil had failed to do, namely, provide the proof that was essential to its case. Exxon claimed it had demonstrated "by clear and cogent evidence" 168 that Wisconsin's apportionment of Exxon's income to the state had produced a "grossly distorted result" 169 "out of all appropriate proportion to the business transacted . . . in that state." 170 The consequence, it asserted, was "a Due Process violation as both the elements of a minimal connection (nexus) and a

166. See Wis. Stat. ANN. $\S \S 71.07(1)$, (2) (West 1969 \& Supp. 1980); Armour \& Co. v. Wisconsin Dept. of Taxation, 252 Wis. 468, 32 N.W.2d 324 (1948). Under present practice, Wisconsin seeks to include dividends received by a nondomiciliary corporation in its apportionable tax base when such dividends derive from property whose acquisition, management, or disposition constitute integral parts of the taxpayer's business. Wisconsin Department of Revenue Rule 2.39(6), reported in STATE AND LoCAL TAXES (Wis.) (P-H) I 10,653.101 (1979); see also Instructions for Wisconsin Corporate Franchise and Income Tax Return, Form 4B, Schedule M-1, reproduced in id. II 11,805, at p. 11,823.

167. During the years in question, Wisconsin's formula for apportioning corporate income was comprised of three equally weighted factors of property, manufacturing costs (including payroll) and sales. WIS. STAT. \& 71.07(2) (1977), quoted, in part, at $100 \mathrm{~S}$. Ct. at $2115 \mathrm{n} .3$. The current version of Wisconsin's formula resembles the one in the earlier statute, the most significant change being that the sales factor is weighted $50 \%$ while the property and payroll factors are each weighted 25\%. WIS. STAT. ANN. \$ 71.07(2) (West Supp. 1980).

168. Norfolk \& W. Ry. v. North Carolina ex rel. Maxwell, 297 U.S. 682, 688 (1936).

169. Norfolk \& W. Ry. v. Missouri State Tax Commn., 390 U.S. 317, 329 (1968).

170. Brief for Appellant at 24, Exxon Corp. v. Wisconsin Dept. of Revenue, $100 \mathrm{~S}$. Ct. 2109 (1980) (quoting Hans Rees' Sons, Inc. v. North Carolina ex rel. Maxwell, 283 U.S. I23, 135 (1931)). See generally Brief for Appellant at 17-44, Exxon Corp. v. Wisconsin Dept. of Revenue, 100 S. Ct. 2109 (1980). 
rational relationship were lacking." 171 To make its evidentiary demonstration - a feat which no income taxpayer had performed successfully before the Supreme Court in fifty years ${ }^{172}$ - Exxon had developed an extensive record based largely on separate functional accounting procedures that purportedly identified the income produced by discrete functional segments of its business.

Exxon first showed that its operations were organized along functional lines. Separate operating departments corresponded to functional segments of Exxon's business. The three principal functional departments were Exploration and Production, Refining, and Marketing. ${ }^{173}$ Each department was organized as a separate and independent operating unit: each had its own management; each was independently responsible for its own performance; and each department's profit was determined separately. The functional departments competed with one another for available investment funds and with other firms in the industry for available supplies. There was no requirement, for example, that crude oil produced by Exploration and Production be transferred to Refining for processing and then to Marketing for ultimate sale as Exxon products. While there were transfers between these departments, the transfers were in principle based on competitive market prices: transfers of crude oil from Exploration and Production to Refining were treated as sales at posted industry prices; transfers of processed products from Refining to Marketing were treated as sales at wholesale market prices. If there was no readily available market price for a product, representatives of the two functional departments involved would negotiate to establish the internal transfer price. ${ }^{174}$

As a result of this organizational arrangement, Exxon was able to demonstrate according to its internal accounting procedures the precise amount of income that each of its functional departments earned. ${ }^{175}$ Relying on these data, Exxon showed that the income in-

171. Brief for Appellant at 14, Exxon Corp. v. Wisconsin Dept. of Revenue, $100 \mathrm{~S}$. Ct. 2109 (1980).

172. See Hans Rees' Sons, Inc. v. North Carolina ex rel. Maxwell, 283 U.S. 123, 134-35 (1931). Unsuccessful attempts were made in Moorman Mfg. Co. v. Bair, 437 U.S. 267 (1978); Butler Bros. v. McColgan, 315 U.S. 501 (1942); Norfolk \& W. Ry. v. North Carolina ex rel. Maxwell, 297 U.S. 682 (1936); and Maxwell v. Kent-Coffey Mfg. Co., 291 U.S. 642 (1934), affg. per curiam, 204 N.C. 365, 168 S.E. 397 (1933). During this period the Court did, however, invalidate the District of Columbia's single-factor sales formula for apportioning corporate income, but on statutory rather than constitutional grounds. General Motors Corp. v. District of Columbia, 380 U.S. 553 (1965).

173. The others were Marine, Coal and Shale Oil, Minerals, and Land Management. 100 S. Ct. at 2114.

174. $100 \mathrm{~S}$. Ct. at 2114.

175. See, e.g., Schedule A to Exhibit 28, reproduced in Wisconsin Dept. of Revenue v. 
cluded in its apportionable tax base by Wisconsin exceeded the income produced by its Marketing Department. ${ }^{176}$ Inasmuch as Exxon's operations in Wisconsin were limited to marketing, Exxon contended that Wisconsin's attempt to include income attributable to functions other than marketing in its apportionable tax base constituted extraterritorial taxation prohibited by the due process clause. ${ }^{177}$ Further, Exxon claimed that its separate accounting data were sufficient to defeat Wisconsin's apportioned tax on all of its income even assuming that Exxon's overall business was unitary.

Exxon's claim was thus grounded on the general propositions that separate accounting can defeat the formulary apportionment of income of a unitary business, and that it can do so by showing either that part of the income is not attributable to business done in the state or that the resulting tax is out of all proportion to business conducted in the state. ${ }^{178}$ Exxon derived support for these propositions from the Court's decision in Hans Rees'Sons, Inc. v. North Carolina ex rel. Maxwell. ${ }^{179}$ Hans Rees invalidated the application of North Carolina's single-factor apportionment formula to the income of a unitary business on the basis of the taxpayer's separate accounting evidence that the income attributed to the state by the formula was grossly in excess of that derived from the state. Exxon also took comfort in language in Moorman Manufacturing Co. v. Bair. ${ }^{180}$ Although the Court in that case dismissed a due process attack on Iowa's single-factor sales formula for apportioning income, it ob-

Exxon Corp., 90 Wis. 2d 700, 727 n.1, 281 N.W.2d 94, 108 n.1 (1979), affd., 100 S. Ct. 2109 (1980).

176. Brief for Appellant at 25-27, Exxon Corp. v. Wisconsin Dept. of Revenue, $100 \mathrm{~S}$. Ct. 2109 (1980).

177. Id. at 17-44. Exxon's original position, reflected in its Wisconsin income tax returns for the years in question, was that its separate geographic accounting procedures actually showed losses for its Wisconsin marketing activities. See $100 \mathrm{~S}$. Ct. at 2115; Wisconsin Dept. of Revenue v. Exxon Corp., 90 Wis. $2 d$ 700, 727 n.1, 281 N.W.2d 94, 108 n.1 (1979), affd, 100 S. Ct. 2109 (1980). During the course of the protracted litigation, Exxon relied principally on separate functional accounting to support its claim that Wisconsin was taxing it unconstitutionally. The effect of this was to concede that Wisconsin could tax an apportioned share of Exxon's marketing income, but not its income from any other operating functions. See $100 \mathrm{~S}$. Ct. at 2118. Although this meant that Exxon would have some Wisconsin taxable income in each of the years in question, the amounts were much less than Exxon's Wisconsin taxable income resulting from the state's approach of including substantially all of Exxon's operating income in its apportionable tax base. 90 Wis. $2 \mathrm{~d}$ at $727 \mathrm{n} .1,281 \mathrm{~N} . \mathrm{W} .2 \mathrm{~d}$ at $108 \mathrm{n} .1$. The Court stated that the principles controlling the weight to be accorded the taxpayer's separate accounting demonstrations were the same whether separate geographic or functional accounting was at issue. $100 \mathrm{~S}$. Ct. at 2120 n.7.

178. Brief for Appellant at 27, Exxon Corp. v. Wisconsin Dept. of Revenue, $100 \mathrm{~S}$. Ct. 2109 (1980).

179. 283 U.S. 123 (1931).

180. 437 U.S. 267 (1978). Moorman is discussed in text at notes 113-29 supra. 
served that the attack might have been upheld had the taxpayer demonstrated, through "any separate accounting analysis showing what portion of appellant's profits was attributable to sales, to manufacturing, or to any other phase of the company's operations,"181 that income attributed to Iowa was in fact generated by non-Iowa operations. To be sure, the Court had earlier declared in Butler Brothers v. McColgan ${ }^{182}$ that a taxpayer's separate accounting evidence, though valid by its own terms and for its own purposes, would not "impeach the validity or propriety" 183 of the application of California's three-factor apportionment formula to the income of a unitary business. Nevertheless, the Court's subsequent comment in Moorman had left unclear what weight, if any, the Court would accord to separate accounting evidence in adjudicating the validity of an income apportionment formula applied to a unitary enterprise.

Wisconsin did not challenge the accuracy of Exxon's separate accounting evidence. Instead, it took issue with Exxon's contention that the company's separate accounting could preclude apportionment of the income from Exxon's unitary business. Wisconsin asserted that it was entitled to include income from Exxon's exploration, production, and refining functions in the company's apportionable tax base along with income from its marketing function, whatever the results of Exxon's separate functional accounting. ${ }^{184}$ The only question, according to the State, was whether the income Wisconsin sought to include in Exxon's apportionable tax base was generated by a unitary business conducted in part in the State. If it was, the argument continued, no separate accounting demonstration, however accurate by its own terms, could impeach the results of Wisconsin's formulary apportionment of Exxon's unitary income. Finally, the State reasoned, since the record amply supported the Wisconsin Supreme Court's determination that Exxon's Wisconsin operations constituted an integral part of its overall unitary petroleum business, ${ }^{185}$ the State's apportioned tax was constitutionally invulnerable.

The Supreme Court largely agreed. Rather than attempting to walk an analytical tightrope between the language and holdings of

181. 437 U.S. at 272.

182. 315 U.S. 501 (1942).

183. 315 U.S. at 508.

184. See Brief for Appellee at 10-33, Exxon Corp. v. Wisconsin Dept. of Revenue, $100 \mathrm{~S}$. Ct. 2109 (1980).

185. Wisconsin Dept. of Revenue v. Exxon Corp., 90 Wis. 2d 700, 281 N.W.2d 94 (1979), affd., 100 S. Ct. 2109. (1980). 
its earlier separate accounting decisions, the Court chose to come down firmly on the side of apportionment - at least in its threefactor configuration - as a method of dividing the income of a unitary business income among states that is virtually unimpeachable by separate accounting. Relying heavily on its opinion in Butler Brothers, the Court held that a state may constitutionally determine a taxpayer's tax base by applying a three-factor apportionment formula to the entire income of a unitary business conducted in part in the state, even if the taxpayer's separate accounting evidence produces results inconsistent with such apportionment. ${ }^{186}$

The Court rejected Exxon's argument that '[a] finding of unitary [business] at the very most provides merely a condition precedent to the right to apply an apportionment formula to the income of the socalled unitary business." 187 Invoking Mobil, the Court ruled that a state has the constitutionally required nexus to all the activities of a unitary business conducted in part in the state, and the state "may apply an apportionment formula to the taxpayer's total income." 188 It held that neither the required nexus nor the right of the state to apply an apportionment formula to a unitary business can be impeached by separate accounting. Separate accounting evidence can exclude income from an apportionable tax base of a unitary business only by proving that "the income [was] derive[d] from 'unrelated business activity' which constitutes a 'discrete business enterprise," "189 that is, in this case, by proving that the sale of petroleum products in Wisconsin and Exxon's nonmarketing activities were not a unitary business in the first place. The Court had little difficulty concluding that Exxon's Wisconsin activities were part of a unitary business. ${ }^{190}$

The Court also considered Exxon's appeal to the second due process restriction on state tax power: the requirement of a rational relationship between the income attributed to a state by its apportionment formula and the intrastate value of the business. ${ }^{191}$ The Court entertained Exxon's separate accounting evidence, thus imply-

186. $100 \mathrm{~S}$. Ct. at 2119 . Exxon had shown that the income Wisconsin sought to include in its apportionable tax base exceeded the income generated by its marketing activities, which were the only activities Exxon conducted in Wisconsin. See text at notes 176-77 supra.

187. Brief for Appellant at 27, Exxon Corp. v. Wisconsin Dept. of Revenue, $100 \mathrm{~S}$. Ct. 2109 (1980).

188. $100 \mathrm{~S}$. Ct. at $2118,2120$.

189. $100 \mathrm{~S}$. Ct. at 2120, quoting Mobil Oil Corp. v. Commissioner of Taxes, 445 U.S. at 439, 442.

190. See $100 \mathrm{~S}$. Ct. at $2120-21$; text at notes $205-28$ infra.

191. See 100 S. Ct. at 2122; Brief for Appellant at 24-30, 35, Exxon Corp. v. Wisconsin Dept. of Revenue, 100 S. Ct. 2109 (1980). 
ing that application of an apportionment formula might be impeached by a separate accounting demonstration that "the State has used its formula to attribute income 'out of all appropriate proportion to the business transacted . . . in that State." "192 Although the Court found inconsistent results between the formula and separate accounting, it held that there was no violation of the rational relation requirement. 193

As for its remarks in Moorman that separate accounting evidence might provide the basis for a successful due process attack on formulary apportionment of income from a unitary business, the Court denigrated them as "dicta". ${ }^{194}$ It first observed that

separate accounting, while it purports to isolate portions of income received in various States, may fail to account for contributions to income resulting from functional integration, centralization of management, and economies of scale.... Although separate ... accounting may be useful for internal auditing, for purposes of state taxation it is not constitutionally required. ${ }^{195}$

It then declared:

In Moorman we simply noted that the taxpayer had made no showing that its Illinois operations were responsible for profits from sales in Iowa. This hardly leads to the conclusion, urged by Exxon here, that a taxpayer's separate functional accounting, if it purports to separate out income from various aspects of the business, must be accepted as a matter of constitutional law for state tax purposes. Such evidence may be helpful, but Moorman in no sense renders such accounting conclusive. ${ }^{196}$

After considering the Court's remarks in Exxon, only the most sanguine taxpayer would harbor the hope that the Supreme Court may still be moved by separate accounting evidence to invalidate the application of a three-factor apportionment formula to the income of a unitary business. The deference that the Court has displayed towards state apportionment formulas in general, ${ }^{197}$ and towards the three-factor formula in particular, ${ }^{198}$ is likely to overcome any separate accounting demonstration that a taxpayer is capable of making,

192. $100 \mathrm{~S}$. Ct. at 2122, quoting Hans Rees' Sons v. North Carolina ex rel. Maxwell, 283 U.S. 123,125 (1931).

193. $100 \mathrm{~S}$. Ct. at 2122 . Exxon's due process challenge was organized into two prongs, each relating to different sources of Exxon's income. Both prongs relied on separate accounting evidence and many of the same precedents. See Brief for Appellant at 17-44, Exxon Corp. v. Wisconsin Dept. of Revenue, 100 S. Ct. 2109 (1980).

194. $100 \mathrm{~S}$. Ct. at 2120.

195. $100 \mathrm{~S}$. Ct. at 2119-20, quoting Mobil Oil Corp. v. Commissioner of Taxes, 445 U.S. 425, 438 (1980).

196. $100 \mathrm{~S}$. Ct. at 2120 (footnote omitted).

197. See, e.g., Moorman Mfg. Co. v. Bair, 437 U.S. 267 (1978).

198. See Butler Bros. v. McColgan, 315 U.S. 501, 509 (1942). Cf. General Motors Corp. v. 
whether on a functional or a geographic basis. ${ }^{199}$.

With the Court's remarks in Moorman deprived of persuasive force, Hans Rees stands alone as an isolated monument to the ability of one taxpayer to use separate accounting evidence to challenge successfully a state's apportionment of unitary business income. Moreover, even Hans Rees may be in harmony with the Court's present views. Hans Rees can, of course, be distinguished from $E x$ $x o n$ as a case in which the high percentage of the taxpayer's income apportioned to the taxing state and the glaring disparity between the result derived from formulary apportionment and separate accounting necessarily raised questions about the fairness and rationality of the state's approach. ${ }^{200}$ But there is a more fundamental distinction between the two cases. Hans Rees involved a single-factor property formula for apportioning income. Despite the Court's frequent rejection of constitutional attacks on the states' use of single-factor formulas, ${ }^{201}$ the Court and individual Justices have voiced concern over the fairness of such formulas. ${ }^{202}$ At the same time, the Court has expressed broad approval of the three-factor formula "as a rough, practical approximation of the distribution of either a corporation's

District of Columbia, 380 U.S. 553, 561 (1965) (invalidating single-factor sales formula on statutory grounds).

199. The Court in Exxon declined to draw any distinction in the weight to be accorded separate functional accounting evidence and separate geographic accounting evidence for constitutional purposes. $100 \mathrm{~S}$. Ct. at 2120 n.7. See also $100 \mathrm{~S}$. Ct. at 2122; note 177 supra.

200. In Hans Rees, the income apportioned by formula to North Carolina for the years in question was approximately $83 \%, 85 \%, 66 \%$, and $85 \%$ of the tax base; the income attributed to the State by separate accounting was less than $22 \%$ of the tax base. In Exxon, the income apportioned by formula to Wisconsin for the years in question was approximately $.19 \%, .23 \%$, $.23 \%$, and $.24 \%$ of the tax base; the income attributed to the state by separate accounting was approximately $.13 \%, .06 \%, .07 \%$, and $.13 \%$ of the tax base as determined by separate functional accounting, and $0 \%$ for all four years as determined by separate geographic accounting, which showed losses from Exxon's operations in Wisconsin for those years. Wisconsin Dept. of Revenue v. Exxon Corp., 90 Wis. 2d 700, 727 n.1, 730 n.2, 281 N.W.2d 94, 108 n.1, 100 n.2 (1979). The Supreme Court noted that the apportionment of a mere $.22 \%$ of Exxon's apportionable income tax base to the state for the years at issue, when considered in light of its substantial sales activity in the state over that period, hardly made it a case "where the State has used its formula to attribute income 'out of all appropriate proportion to the business transacted . . . in that State," $100 \mathrm{~S}$. Ct. at 2122 (citing Hans Rees), or where application of the state's formula " "led to a grossly distorted result." " $100 \mathrm{~S}$. Ct. at 2122 (citing Norfolk \& W. Ry. v. Missouri State Tax Commn., 390 U.S. 317, 326 (1968)).

201. See Moorman Mfg. Co. v. Bair, 437 U.S. 267 (1978); Kent-Coffey Mfg. Co. v. Maxwell, 291 U.S. 642 (1934), affg. per curiam, 204 N.C. 365, 168 S.E. 397 (1933); Bass, Ratcliff \& Gretton, Ltd. v. State Tax Commn., 266 U.S. 271 (1924); Underwood Typewriter Co. v. Chamberlain, 254 U.S. 113 (1920).

202. See Moorman Mfg. Co. v. Bair, 437 U.S. 267, 282-83 (1978) (Blackmun, J., dissenting) (characterizing such formulas as "relics of the early days of state income taxation"), 437 U.S. at 283-97 (Powell, J., dissenting); General Motors Corp. v. District of Columbia, 380 U.S. 553,561 (1965). 
sources of income or the social costs that it generates."203 Hence, the Court may still be receptive to a "separate accounting" constitutional challenge to a single-factor formula like North Carolina's in Hans Rees or Iowa's in Moorman, because of its belief that such formulas are unlikely to reflect fairly the distribution of the income of a multistate enterprise and thus may fail to satisfy the rational relationship requirement of due process. On the other hand, while it may be an overstatement to conclude that the application of a threefactor apportionment formula to the income from a unitary business meets the rational relationship requirement as a matter of law (despite any sort of separate accounting demonstration), the results, if not the reasoning, of future cases are likely to support such a conclusion. ${ }^{204}$

\section{The Scope of a Unitary Business}

In addition to disposing of the separate accounting issue, the Court considered the due process limits on the scope of a unitary business for state income tax purposes. Since the existence of a unitary business is an essential predicate to a state's apportionment of income generated by that business, ${ }^{205}$ the criteria for determining whether a business is unitary are crucial. Over the years, the Supreme Court has provided general guidance for this task without committing itself to any particular approach. Thus, the Court has considered as unitary those enterprises whose "ultimate gain is derived from the entire business" 206 or whose income is earned by a "series of transactions" in different states so that it is impossible to allocate specifically the income earned within any one of them. ${ }^{207}$ It has adverted to such factors as unity of ownership, management and use in characterizing a business as unitary. ${ }^{208}$ And it has observed that "the enterprise of a corporation which manufactures and sells its manufactured product is ordinarily a unitary business."209

In the absence of a more definitive instruction from the Supreme

203. General Motors Corp. v. District of Columbia, 380 U.S. 553, 561 (1965). See also Butler Bros. v. McColgan, 315 U.S. 501, 509 (1942).

204. It is not clear what the Court's attitude would be were it confronted with an intermediate case as, for example, West Virginia's two-factor formula of property and payroll, W. VA. CODE \& 11-24-7(d)(5) (1974), or Massachusetts' formula that gives double weight to the sales factor. Mass. ANN. Laws ch. 63, § 38(c) (Law. Co-op. 1978, Supp. 1980). See also note 164 supra.

205. See text at notes 186-89 supra.

206. Hans Rees' Sons, Inc. v. North Carolina ex rel. Maxwell, 283 U.S. 123, 133 (1931).

207. Underwood Typewriter Co. v. Chamberlain, 254 U.S. 113, 120-21 (1920).

208. See Butler Bros. v. McColgan, 315 U.S. 501, 508 (1942).

209. Hans Rees' Sons, Inc. v. North Carolina ex rel. Maxwell, 283 U.S. 123, 133 (1931). 
Court, state courts have tried their own hands at delineating the scope of a unitary business. Two of the leading formulations have emanated from the California Supreme Court. It laid the groundwork for the United States Supreme Court's opinion in Butler Brothers by declaring in that case that

the unitary nature of appellant's business is definitely established by the presence of the following circumstances: (1) Unity of ownership; (2) Unity of operation as evidenced by central purchasing, advertising, accounting and management divisions; and (3) unity [sic] of use in its centralized executive force and general system of operation. ${ }^{210}$

The California court subsequently provided an alternative formulation of the test for determining whether a business is unitary: "If the operation of the portion of the business done within the state is dependent upon or contributes to the operation of the business without the state, the operations are unitary."211 Other state courts have articulated the definition of a unitary business in terms of the interdependence of the enterprise's operating units, ${ }^{212}$ the centralization of corporate management or corporate staff personnel, ${ }^{213}$ the mutual benefit that various parts of the enterprise derive from each other, ${ }^{214}$ the essentiality of one part of the enterprise to the other parts, ${ }^{215}$ and the overall impact of the parts of the enterprise on the economic performance of the whole. ${ }^{216}$ Scholars have likewise entered the fray, variously lauding and criticizing the tests adopted by the courts and advancing suggestions of their own. ${ }^{217}$

The Court in Exxon did not canvass the possible formulations of a unitary business or address their relative merits, despite the atten-

210. Butler Bros. v. McColgan, 17 Cal. 2d 664, 678, 111 P.2d 334, 341 (1941), affd, 315 U.S. 501 (1942). Accord, e.g., W.S. Dickey Clay Mfg. Co. v. Dickinson, 200 Tenn. 25, 34, 289 S.W.2d 533, 537 (1956).

211. Edison California Stores, Inc. v. McColgan, 30 Cal. 2d 472, 481, 183 P.2d 16, 21 (1947). Accord, e.g., Zale-Salem, Inc. v. State Tax Commn., 237 Or. 261, 265, 391 P.2d 601, 602 (1964).

212. See, e.g., Commonwealth v. Advance-Wilson Indus., Inc., 456 Pa. 200, 203, 317 A.2d 642, 644-45 (1974).

213. See, e.g., W.R. Grace \& Co. v. Commissioner of Revenue, - Mass. -, - 393 N.E.2d 330, 336 n.10 (1979).

214. See, e.g., Crawford Mfg. Co. v. State Commn. of Revenue \& Taxation, 180 Kan. 352, 359, 304 P.2d 504, 510 (1956).

215. See, e.g., Skelly Oil Co. v. Commissioner of Taxation, 269 Minn. 351, 367-68, 131 N.W.2d 632, 643 (1964).

216. See, e.g., Wisconsin Dept. of Revenue v. Exxon Corp., 90 Wis. 2d 700, 718, 281 N.W.2d 94, 104 (1979). It is self-evident that the various formulations or considerations cited are not mutually exclusive. Indeed, courts frequently invoke two or more of them in addressing the unitary business issue. See, e.g., 90 Wis. at 711, 281 N.W.2d at 100 (adopting "dependent upon or contributory" test).

217. See authorities cited in note 51 supra. 
tion that was devoted to them in the briefs. ${ }^{218}$ Rather, the Court adhered to its catholic approach by stressing a number of factors, many of them familiar, in justifying its conclusion that Exxon's overall operations constituted a unitary business conducted in part in Wisconsin. The Court recounted the record, which indicated that Exxon was a corporate entity with centralized management - supervision of the Wisconsin marketing district was exercised from regional and national headquarters, for example - and with centralized corporate staff departments providing a wide range of critical services for the entire corporation. ${ }^{219}$ Moreover, although Exxon's Wisconsin activities were limited to marketing, the Court pointed out that these activities were interdependent with the company's integrated operations at the national level, and that the whole derived benefit from the sum of its parts, including marketing. ${ }^{220}$ In particular, Exxon employed centralized purchasing to enhance company-wide profits, ${ }^{221}$ intradepartmental coordination to achieve operating efficiencies, nationwide distribution and uniform brand names, advertising, credit cards, and packaging to facilitate sales, and a host of other important links between its three principal operating departments to provide "an assured supply of raw materials[,] ... stable outlet[s] for products[,] . . . and greater profits stability," 222 for the entire corporate enterprise. In the Court's view Exxon was a "highly integrated business which benefits from an umbrella of centralized management and controlled interaction."223

The Court was able to focus on all of these considerations and remain uncommitted to any specific formulation of the unitary business concept because Exxon presented an easy case. In light of the facts of its operations, Exxon would have been found to be a unitary business under almost any approach. ${ }^{224}$ No doubt the Court will

218. See Brief for Appellant at 17-30, Exxon Corp. v. Wisconsin Dept. of Revenue, $100 \mathrm{~S}$, Ct. 2109 (1980); Brief for Appellee at 10-25; Brief Amicus Curiae for the Multistate Tax Commission and Participating States at 46-64.

219. $100 \mathrm{~S}$. Ct. at 2114.

220. $100 \mathrm{~S}$. Ct. at $2120-21$.

221. Petroleum and petroleum products sold by Exxon in Wisconsin were manufactured elsewhere and shipped into the state from central warehouse facilities in Chicago. Tires, batteries and accessories were centrally purchased through Exxon's national headquarters and shipped into Wisconsin for resale. The gasoline Exxon sold in Wisconsin was obtained from another company under an exchange arrangement that was negotiated on Exxon's behalf by two departments other than Marketing: Supply, a corporate staff department, and Refining. See 100 S. Ct. at 2115.

222. $100 \mathrm{~S}$. Ct. at 2121 (quoting the record testimony of an Exxon vice president).

223. $100 \mathrm{~S}$. Ct. at 2120.

224. Except, perhaps, under a test stressing the essentiality of one part of the enterprise to the other parts. See note 215 supra and accompanying text. 
someday be confronted with the harder cases involving nonintegrated businesses that share some corporate staff services but are otherwise independent enterprises. ${ }^{225}$ At that point, the Court may have to refine its eclectic approach to the unitary business issue. In the meantime, the Court's unwillingness to settle upon a single definition of a unitary business is consistent with its view that the states should be free within broad limits to tax interstate business by any method that in design and effect attributes a reasonable share of the business' income to the taxing state. By adverting to virtually all of the considerations that have been embodied in the various formulations of the unitary business concept, the Court left the door open to approval of any particular formulation that satisfies its generous view of state taxing authority. Indeed, in light of the wide variety of overlapping and inconsistent ${ }^{226}$ formulations of the unitary business concept, all of which are arguably embraced within the views expressed by the Supreme Court, the concept may not retain any force as a meaningful restraint on the applicability of an apportionment formula to an enterprise's income.227 While the concept may serve to limit the reach of a state's apportionment formula in those jurisdictions where it has been narrowly defined, ${ }^{228}$ the present posture of the Supreme Court provides few curbs on the scope of the unitary business concept under the due process clause.

\section{B. Commerce Clause Limitations on State Taxation of a Unitary Business}

Like Mobil, Exxon invoked the commerce clause as well as the due process clause to challenge the application of the state's taxing scheme to its income, contending that the levy violated the commerce clause by subjecting the company to a multiple tax burden not borne by local business. Moreover, despite the differences alluded to earlier ${ }^{229}$ between the controversies in Mobil and Exxon, the commerce clause claims in the two cases were remarkably similar. Mobil

225. Cf. W.R. Grace \& Co. v. Commissioner of Revenue, - Mass. -, 393 N.E.2d 330 (1979) (the Massachusetts business activities of W.R. Grace \& Co. and the sale by W.R. Grace \& Co. of its controlling interest in Miller Brewing Co. held unitary).

226. Compare, e.g., Texas Co. v. Cooper, 236 La. 380, 107 So. 2 d 676 (1958), with Superior Oil Co. v. Franchise Tax Bd., 60 Cal. 2d 406, 386 P.2d 33, 34 Cal. Rptr. 545 (1963). See J, Hellerstein, Recent Developments in State Tax Apportionment and the Circumscription of Unitary Business, 21 NaTL. TAX J. 487, 496-503 (1968).

227. See Boren, Separate Accounting in California and Uniformity in Apportioning Corporate Income, 18 UCLA L. REv. 478, 494-96 (1971); Keesling, $A$ current look at the combined report and uniformity in allocation practices, $42 \mathrm{~J}$. TAX. 106, 109 (1975).

228. As, for example, in Pennsylvania and Minnesota. See notes 212 \& 215 supra.

229. See text at notes 166-67 supra. 
asserted that Vermont's power to tax an apportioned share of Mobil's dividend income subjected that income to the risk of multiple taxation because of the power of the state of Mobil's commercial domicile to tax all such income. Exxon asserted that the power of Wisconsin to tax an apportioned share of Exxon's exploration and production income ${ }^{230}$ subjected that income to the risk of multiple taxation because of the power of the states where the exploration and production occurred to tax all such income. Just as Mobil had insisted that the commerce clause therefore required that all of its dividend income be allocated to the state of its commercial domicile to avoid the risk of multiple taxation, so Exxon insisted that the commerce clause required that all of its exploration and production income be allocated to the states where the exploration and production occurred to avoid a comparable risk. ${ }^{231}$

Unsurprisingly, the Supreme Court rejected Exxon's commerce clause argument, largely for the reasons set forth in Mobil. The Court entertained the claim, as it had in Mobil, even though the taxpayer was relying on the risk rather than the actuality of multiple taxation. ${ }^{232}$ But, as in Mobil, the Court chose apportionment rather than allocation of the income from the unitary business when forced to choose between the two as a matter of constitutional law. Tracking its reasoning in Mobil, the Court in Exxon declared:

Presumably, the States in which appellant's crude oil and gas production is located are permitted to tax in some manner the income derived from that production, there being an obvious nexus between the taxpayer and those States. However, "there is no reason in theory why that power should be exclusive when the [exploration and production income as distinguished through separate functional accounting] reflect[s] income from a unitary business, part of which is conducted in other States. In that situation, the income bears relation to benefits and privileges conferred by several States. These are the circumstances in which apportionment is ordinarily the accepted method."233

The Court's preference for apportionment over allocation has implications not only for states seeking to tax an apportioned share of a taxpayer's income (or particular income items) but also for states seeking to tax all such income (or such income items). If the Supreme Court permits Vermont to tax an apportioned share of Mobil's dividend income and Wisconsin an apportioned share of Ex-

230. As identified by its separate functional accounting. See Exxon Corp. v. Wisconsin Dept. of Revenue, 100 S. Ct. 2109,2123 (1980).

231. See $100 \mathrm{~S}$. Ct. at $2122-23$.

232. $100 \mathrm{~S}$. Ct. 2123; see text at notes 109-29 supra.

233. $100 \mathrm{~S}$. Ct. at 2123 (quoting Mobil Oil Corp. v. Commissioner of Taxes, 445 U.S. 425 , 445-46 (1980) (brackets in original)). 
xon's exploration and production income, it follows that New York may tax no more than an apportioned share of Mobil's dividend income and Alaska or Texas no more than an apportioned share of Exxon's exploration and production income ${ }^{234}$ - assuming that the Court continues to hold the risk rather than the fact of multiple taxation to be the governing principle. Moreover, the same analysis would apply to other income items over which there is currently debate about whether they are apportionable or allocable - such as interest, ${ }^{235}$ patent and copyright royalties, ${ }^{236}$ and capital gains ${ }^{237}$ in the event that they were ultimately held to be apportionable.

In light of the constitutional challenges rejected by the Court in Mobil and Exxon, ${ }^{238}$ the expansiveness of the Court's view of state taxing power seems clear. Mobil, on one hand, held that a state can apply formulary apportionment to foreign source dividends from subsidiaries and affiliates of a nondomiciliary corporation engaged in a unitary business in the state. On the other hand, it did not consider the alleged unfairness of the particular apportionment at issue, thus leaving the states with the broad leeway they have traditionally exercised in apportioning corporate income. Exxon, on one hand, held that a state's application of a three-factor apportionment formula to the operating income of a unitary business is virtually unimpeachable by the taxpayer's separate accounting evidence. On the other hand, the Court failed to define the constitutional limits to the unitary business principle, thus leaving the states free to apply fair apportionment methods to very loosely connected enterprises. The Court's failure to articulate more rigorous restraints on state taxing authority may well encourage Congress to enact restrictions of its own, the subject of part III of this Article.

234. In Alaska, these implications are not merely hypothetical. See ALASKA STAT. $\S \S 43.21 .010-120$ (Supp. 1979), which is presently under constitutional attack in the Alaska courts. 58 State aNd Local TAXes (All State Unit) (Report Bulletin) (P-H) I 17.8 (Oct. 21, 1980).

235. See, e.g., Qualls v. Montgomery Ward \& Co., 266 Ark. 207, 585 S.W.2d 18 (1979).

236. See, e.g., American Smelting \& Ref. Co. v. Idaho State Tax Commn., 99 Idaho 924, 592 P.2d 39 (1979), vacated and remanded sub nom. Asarco, Inc. v. Idaho State Tax Commn., $100 \mathrm{~S}$. Ct. 1223 (1980) (remanded for further consideration in light of Mobil Oil Corp. v. Commissioner of Taxes, 445 U.S. 425 (1980)).

237. See, e.g., Johns-Manville Prods. Corp. v. Commissioner of Revenue Administration, 115 N.H. 428, 343 A.2d 221 (1975), appeal dismissed, 423 U.S. 1069 (1976).

238. A week after its decision in Exxon, the Court dismissed an appeal in a case virtually identical to the one it had just decided, except that it arose in South Carolina. Exxon Corp. v. South Carolina Tax Commn., - S.C. -, 258 S.E.2d 93 (1979), appeal dismissed, 100 S. Ct. 3005 (1980). 


\section{H.R. 5076: Proposed Federal Legislation Restricting State Taxation of Foreign Source Income}

Ever since 1959, when Congress first imposed limitations on the states' power to tax interstate commerce, ${ }^{239}$ the promise of further federal intervention in the state tax field ${ }^{240}$ has remained largely unfulfilled. ${ }^{241}$ The oft-told tale of congressional fits and starts over proposed legislation bears no repeating here. ${ }^{242}$ As indicated at the outset, ${ }^{243}$ however, recent developments, including the Court's decisions in Mobil and Exxon, may set the stage for federal legislation significantly limiting state tax power.

The legislative proposal that has recently generated the most interest is H.R. 5076 ${ }^{244}$ and its Senate counterpart, S. 1688.245 The proposal differs from other recent bills ${ }^{246}$ because it is directed only at state taxation of foreign source income. ${ }^{247}$ It imposes two distinct limitations on the power of the states to tax foreign source income or to consider such income in their taxing schemes. ${ }^{248}$ First, it generally prevents states levying corporate income taxes from taking into ac-

239. See note 3 supra.

240. At the time that it enacted Pub. L. No. $86-272$ (codified at 15 U.S.C. $\$ 381$ (1976)), see note 11 supra, Congress directed committees of the Senate and House to undertake complete studies of all matters pertaining to the taxation by the States of income derived within the States from the conduct of business activities. . . which are part of interstate commerce, for the purpose of recommending to the Congress proposed legislation providing uniform stardards to be observed by the States in imposing income taxes on income so derived.

Act of Sept. 14, 1959, Pub. L. No. 86-272, § 201, 73 Stat. 556 (repealed 1976). The result was the extensive and invaluable four-volume Willis Committee Report. SPECIAL SUBCOMM. ON State Taxation of Interstate Commerce of the House Comm. on the Judiciary, State Taxation of Interstate Commerce, H.R. Rep. No. 1480, 88th Cong., 2d Sess. (1964); H.R. REP. Nos. 565 \& 952, 89th Cong., 1st Sess. (1965).

241. See note 3 supra.

242. The history is reviewed in W. Hellerstein, State Taxation of Interstate Business and the Supreme Court, 1974 Term: Standard Pressed Steel and Colonial Pipeline, 62 VA. L. Rev. 149, 151-54 (1976), and in the sources cited therein. For more recent developments, see House Foreign Source Income Hearing, supra note 4; Senate Foreign Source Income Hearing, supra note 4; Interstate Taxation: Hearings on S. 2173 Before the Senate Comm. on the Judiciary, 95th Cong., Ist \& 2d Sess. (1977-1978); Tax Treaty Hearings, supra note 5.

243. See text at notes 1-14 supra.

244. 96th Cong., 1st Sess. (1979).

245. 96th Cong., Ist Sess. (1979). For ease of reference, the legislative proposal will be referred to hereafter solely by reference to the House bill number, and references to hearings on the proposal will be solely to the hearing on the House Bill, House Foreign Source Income Hearing, supra note 4, which was identical in substance to the hearing on the Senate bill. Senate Foreign Source Income Hearing, supra note 4.

246. See S. 983, 96th Cong., 1st Sess. (1979); H.R. 5, 96th Cong, 1st Sess. (1979); S. 2173, 95th Cong., Ist Sess. (1977).

247. See note 284 infra and accompanying text.

248. H.R. 5076 provides:

Be it enacted by the Senate and House of Representatives of the United States of America in Congress assembled, That (a) chapter 77 of the Internal Revenue Code of 1954 
count the income of any foreign corporation affiliated with a corporation that is taxable in the state, unless such income is subject to federal income tax. ${ }^{249}$ Second, it restricts the states' power to levy corporate income taxes on dividends received from foreign corporations or from domestic corporations whose income derives largely

(relating to miscellaneous provisions) is amended by adding at the end thereof the following new section:

$\$ 7518$. Income of corporations attributable to foreign corporations.

(a) In general. - For purposes of imposing an income tax on any corporation, no State, or political subdivision thereof, may take into account, or include in income subject to such tax, any amount of income of, or attributable to, any foreign corporation which is a member of any affiliated group of corporations which includes both such corporations unless such amount is includable in the gross income of such corporation for purposes of chapter 1 (including any amount includable in gross income under subpart $F$ or part III of subchapter $N$ of chapter 1) for the taxable year in which or with which the taxable period (for purposes of State or local law) ends.

(b) Income tax defined. - For purposes of this section, the term "income tax" means any tax which is imposed on, according to, or measured by income.

(c) Affiliated group defined. - For purposes of subsection (a), the term "affiliated group" means a common parent corporation and one or more chains of corporations connected through stock ownership with such common parent corporation.

(d) Certain corporations treated as foreign corporations. - For the purpose of this section, a domestic corporation shall be treated as a foreign corporation if under section $861(a)(2)(A)$ a dividend received from such corporation in the taxable year referred to in subsection (a) would not be treated as income from sources within the United States.

(e) Certain dividends paid or deemed paid. -

(1) Dividends excluded from tax. - If a corporation receives in any taxable year a dividend from a foreign corporation (or is by application of section 951 treated as having received such a dividend), in imposing an income tax on such corporation no State, or political subdivision thereof, may tax, or otherwise take into account -

(A) in the case of a dividend received from a corporation described in subsection (d), the amount of the deduction allowed by section 243 or the amount not taken into accoun in determining the tax liability of an affiliated group of corporations in accordance with section 1502 , or

(B) in the case of a dividend to which subparagraph (A) does not apply, more than the lesser of -

(i) the amount of the dividend (exclusive of any amount determined under section 78), or

(ii) the amount by which the dividend plus any amount determined under section 78 exceeds the excluded portion of the dividend determined in accordance with paragraph (2).

(2) Excluded portion of a dividend. - The excluded portion of any dividend shall be determined by multiplying the amount of the dividend (including any amount determined under section 78) by a fraction -

(A) the numerator of the fraction shall be the sum of -

(i) the total amount of tax withheld from all such dividends at the source, and

(ii) the total amount of tax which by application of section 902 or section 960 to all such dividends, the domestic corporation is deemed to have paid.

(B) The denominator of the fraction shall be 46 percent of all such dividends. For the purposes of this section, only a tax for which a credit against tax would be allowed under section 901 (determined without regard to the limitation in section 904) shall be taken into account.

(b) Effective date. - The amendment made by this section shall apply to taxable periods (for purposes of State or local law) beginning after December 31, 1978.

(c) Amendment of the table of sections. - The table of sections for chapter 77 of such Code is amended by adding at the end thereof the following new item:

Sec. 7518. Income of corporations attributable to foreign corporations.

249. H.R. 5076, 96th Cong., Ist Sess. § (a) (1979) (new I.R.C. § 7518(a)-(d)). 
from foreign sources. ${ }^{250}$ Because bills similar to H.R. 5076 are very likely to be introduced in the current session of Congress, and because H.R. 5076 not only revises the holding in Mobil but also greatly restricts state taxation of foreign source income, it is appropriate to consider the proposed legislation in light of the issues that have been examined above.

\section{A. H.R. 5076: Prohibiting Worldwide Combination}

H.R. 5076 generally forbids a state from taking into account the income of foreign affiliates of corporations taxable in that state unless such income is subject to federal income tax. ${ }^{251}$ It is no secret that this provision is directed at the method of reporting income for corporate tax purposes, now employed by California and several other states, which requires that the income of foreign affiliates of a corporation taxable in the state be included in the total income subject to apportionment if the activities of the corporations are part of a unitary business. ${ }^{252}$ This method of reporting is generally referred to as worldwide combination: combination, because all of the income and apportionment factors of the corporations carrying on a unitary business are combined (and intercompany items eliminated) for tax purposes; worldwide, because the combination does not stop at the water's edge. 253

By prohibiting the states from taking account of foreign affiliate income unless such income is subject to federal taxation, H.R. 5076 effectively precludes the states' use of worldwide combination. For state tax purposes, the worldwide combined tax base of an affiliated group of corporations embraces the foreign source income of foreign members of the group. The federal tax laws, by contrast, generally do not subject foreign source income of foreign corporations to taxation. There are limited exceptions to the federal rule of nontaxability of such income, ${ }^{254}$ but H.R. 5076, if enacted, would accomplish

250. H.R. 5076, 96th Cong., 1st Sess. § (a) (1979) (new I.R.C. \& 7518(d)-(e)).

251. H.R. 5076, 96th Cong., 1st Sess. \& (a) (1979) (new I.R.C. \& 7518(a)).

252. See Foreign Source Income Hearing, supra note 4, passim. For a review of the background to the controversy, the development of California's approach to the unitary business problem, and the use of the combined report in apportioning the income of multicorporate enterprises, see J. HellersteIN \& W. Hellerstein, supra note 16, at 512-14, 520-24, 537-43.

253. It was this method that Mobil suggested was available to Vermont if the State wished to tax Mobil properly on a unitary basis. See text at notes 56-57 supra.

254. Foreign source income of foreign corporations is subject to federal income tax when it is distributed as a dividend to a domestic shareholder, I.R.C. $\$ \$ 11,61(7), 63(\mathrm{a})$, or when it is included in the tax base of a domestic corporation under the special rules governing foreign tax havens, I.R.C. $\$$ \$ 951-964 (subpart F), or under the rules governing allocation of income among related entities to prevent evasion of taxes or clearly to reflect income. I.R.C. $\$ 482$. 
its framers' objective of putting an end to worldwide combination as it is presently employed by the states. ${ }^{255}$

Supporters of H.R. 5076 advance a number of reasons for the proposed limitation on state taxing authority. First, they contend that, however appropriate the unitary business principle and the combined report may be for enterprises carrying on business exclusively within the United States, extending the unitary concept to foreign income earned by foreign entities creates substantial distortions in the income attribution process. Given the dramatic differences between domestic and foreign property values, wage rates, and sales margins, supporters of the bill argue that lumping together foreign and domestic property, payroll and sales factors into a single formula for apportioning the aggregate income of the combined group does not fairly represent the income earned in a particular jurisdiction. ${ }^{256}$ For example, if wage rates in California are significantly higher than analogous wage rates in foreign jurisdictions, the use of a worldwide payroll factor may apportion an excessive amount of income to California, assuming that the different wage rates do not reflect different levels of productivity. Moreover, supporters assert, because the levels of risk are often higher abroad than in the United States, the relationships of property, payroll and sales to income are not uniform on a global basis. ${ }^{257}$ They claim that formulary apportionment (on which worldwide combination depends) relies on an underlying premise that equal wage rates, property and sales in two areas produce the same profits; if unit labor and unit property costs in the United States are higher than in foreign taxing jurisdictions because of lower risk, worldwide combination results in the attribution of a disproportionately large amount of profits to American taxing jurisdictions. ${ }^{258}$ The result allegedly has been international double taxation. ${ }^{259}$

Second, supporters of H.R. 5076 contend that worldwide combination imposes intolerable administrative burdens on multinational business. Under prevailing international standards for dividing the

255. Dividends from a foreign affiliate will normally be eliminated from the combined state tax base as an intercompany item, and subpart F, I.R.C. $\$ \$ 951-964$, and I.R.C. $\$ 482$ provide only limited exceptions to the general federal rule of nontaxability of a foreign corporation's foreign source income.

256. See, e.g., House Foreign Source Income Hearing, supra note 4, at 165 (statement of Paul W. Cook on behalf of the National Association of Manufacturers). Sells).

257. See, e.g., id. at 259-60 (statement of William O. Hetts, partner, Deloitte Haskins \&

258. See J. Hellerstein \& W. Hellerstein, supra note 16, at 539.

259. See, e.g., House Foreign Source Income Hearing, supra note 4, at 315 (statement of Joseph H. Guttentag on behalf of the Dutch Employers' Federation). 
income of an affiliated group of corporations, the separate identities of the different members of the group are respected. This practice is generally followed under section 482 of the Internal Revenue Code, as well. ${ }^{260}$ The different format required by the state for purposes of its combined report, which does not respect separate corporate identies, thus requires taxpayers annually to conform the financial records of sometimes numerous corporate affiliates to the states' requirements, a task that may be overwhelming. ${ }^{261}$ Providing information unavailable from existing records ${ }^{262}$ or protected from disclosure under the law of a foreign country ${ }^{263}$ raises additional difficulties, as does the necessity of making foreign currency translations. ${ }^{264}$

Third, worldwide combination is, according to its critics, a significant international irritant. For the reasons just mentioned, foreign businessmen and their national representatives perceive it as analytically indefensible, contrary to accepted international standards of income attribution, a source of administrative nightmares, and a basis of gross overreaching by state taxing authorities. ${ }^{265}$ This purportedly produces international tension, ${ }^{266}$ creates risks of foreign retaliation, ${ }^{267}$ and threatens losses in foreign investment in the United States. ${ }^{268}$

260. See, e.g., id. at 4 (statement of Hon. Donald C. Lubick, Assistant Secretary of the Treasury for Tax Policy). Under prevailing international and federal standards, the separate status of separately incorporated entities is generally respected for tax purposes. Section 482 of the Internal Revenue Code provides, however, for reallocation of income among related entities when necessary "to prevent evasion of taxes or clearly to reflect the income" of any such entity. I.R.C. \$ 482. Pursuant to this section and the elaborate Treasury regulations issued thereunder, attributing an appropriate share of income to each member of an affiliated group of corporations is achieved by comparing transactions between members of the affiliated group with transactions that would have occurred at arm's length between independent entities operating in the open market. See generally Note, Multinational Corporations and Income Allocation Under Section 482 of the Internal Revenue Code, 89 HARV. L. REV. 1202 (1976).

261. See, e.g., House Foreign Source Income Hearing, supra note 4, at 196 (statement of Thomas P. Maletta, Vice President - Taxes, Allegheny Ludlum Industries, Inc.).

262. See, e.g. , id. at 368 (letter from Donald K. Frick, Chairman, Committee on Taxation, Financial Executives Institute).

263. See, e.g. , id. at 226 (statement of Kirby A. Scott, Director of Taxes, Capitol Industries - EMI, Inc.).

264. See, e.g., id. at 348 (statement of J. Robert Vastine, Chairman, Legislative Committee, California Council for International Trade).

265. See, e.g., id. at 285-308 (statement of John S. Nolan, Counsel, on behalf of the Confederation of British Industry and the British National Committee of the International Chamber of Commerce).

266. See, e.g., id. at 316 (statement of Connie Borken-Hagen, Special Coordinator for the American Chamber of Commerce in the United Kingdom).

267. See, e.g., id. at 182 (statement of James W. McGrath, Director, Domestic Tax Law, R.J. Reynolds Industries, Inc.).

268. See, e.g., id. at 179 (statement of Charles S. Levy, Vice President, Emergency Committee for American Trade). 
Worldwide combination has its champions, however. Opponents of H.R. 5076 assert that the application of the unitary business concept and the combined report on a worldwide basis is simply the logical extension of basic principles that underlie state apportionment methods. ${ }^{269}$ They claim that imposition of federal income attribution criteria upon the states would not only violate fundamental precepts of federalism ${ }^{270}$ but would also substitute the theoretically deficient and administratively unworkable federal arm's-length standards of section 482 for the simple, accurate, and equitable methods traditionally employed by the states. ${ }^{271}$ They decry the loss in state revenues that H.R. 5076 would allegedly cause, ${ }^{272}$ and they caution that the bill would permit multinational corporations to avoid full accountability to the jurisdictions in which the corporations earn their income. ${ }^{273}$ Supporters of worldwide combination challenge business spokesmen to produce real and widespread rather than hypothetical and isolated examples of overtaxation resulting from worldwide combination. ${ }^{274}$ As for the distortion allegedly produced by combining apportionment factors on a global basis, defenders of worldwide combination contend: "[N]obody has made a study. And nobody can really determine the amount of income that should be attributed to the United States because of U.S. know-how, whether it is management, patents, or copyrights."275 In short, proponents of worldwide combination view H.R. 5076 as "vicious, special interest legislation ... [that] would greatly restrict the ability of the states to impose fair and equitable taxes on corporations."276

Resolution of the issues surrounding worldwide combination will not be easy. The debate is likely to be shaped by an extensive General Accounting Office (GAO) report on state and federal taxation of multijurisdictional corporations, a report under preparation as

269. See, e.g., id. at 52-53 (statement of James Hamilton, Assistant Chief Counsel, California State Franchise Tax Board).

270. See, e.g., id. at 361 (letter from Thomas K. Williams, Commissioner, State of Alaska Department of Revenue).

271. See, e.g., id. at 28-29 (statement of William D. Dexter, General Counsel, the Multistate Tax Commission).

272. See, e.g., id. at 48 (statement of James B. Zagel, Director, Department of Revenue, State of Illinois).

273. See, e.g. id. at 19 (statement of Byron Dorgan, Past Chairman, Multistate Tax Commission and Tax Commissioner, State of North Dakota).

274. See, e.g., id. at 34 (statement of Kenneth Cory, State Controller, California Franchise Tax Board).

275. Id. at 37 (statement of Theodore W. de Looze, Chief Tax Counsel, Department of Justice, State of Oregon).

276. Id. at 383 (letter from Frank M. Keesling, Loeb \& Loeb). 
this Article goes to press. ${ }^{277}$ The report will shed light on the relative merits of formulary apportionment versus separate accounting as a means of dividing the income of multinational corporations on a global basis; the extent of undertaxation or overtaxation resulting from existing approaches to income attribution; and the administrative burdens, from both compliance and enforcement standpoints, associated with state and federal methods of attributing the income of multijurisdictional corporations. Detailed analysis of the issues raised by any legislative proposal affecting state taxation of interstate or foreign commerce should therefore await the enlightenment that the GAO report should provide. Nevertheless, some general observations regarding the debate over H.R. 5076's prohibition on worldwide combination are appropriate.

First, Congress should start from the premise that, absent some pressing need for federal intervention in this area, the states should be free to go their own way. Our constitutional system contemplates concurrent state and federal taxation, with considerable latitude accorded to the states in this domain. ${ }^{278}$ There is nothing in the constitutional plan to suggest that adoption by the federal government of a particular mode of taxation creates a duty on the states to follow in its footsteps. ${ }^{279}$ A proper respect for the role of the states in the federal system counsels congressional restraint in imposing such a duty on the states. Although it possesses the constitutional power to do so, ${ }^{280}$ Congress should not require the states to conform to the federal model merely because it has selected a different method of taxation or a different tax policy than the states. Rather, Congress should tolerate diversity except where compelling considerations, such as the need to avoid international conflict, require conformity between state and federal taxation schemes.

Second, assuming that worldwide combination is in fact a problem that demands a federal legislative solution, the cure should be fice).

277. See id. at 356-59 (letter from Allen R. Voss, Director, U.S. General Accounting Of-

278. See The Federalist No. 32 (A. Hamilton); McCulloch v. Maryland, 17 U.S. (4 Wheat.) 316,425 (1819) (dictum):

That the power of taxation is one of vital importance; that it is retained by the States; that it is not abridged by the grant of a similar power to the government of the Union; that it is to be concurrently exercised by the two governments: are truths which have never been denied.

279. See Mobil Oil Corp. v. Commissioner of Taxes, 445 U.S. 425 , 448 (1980); text at note 158 supra.

280. See Arizona Pub. Serv. Co. v. Snead, 441 U.S. 141 (1979) (Congress can invalidate a state tax if it has a rational basis for concluding that the state tax interferes with interstate commerce). 
responsive to the disease. Judging by the "horror cases" 281 that have been paraded before various congressional committees as proof of the evils of worldwide combination, ${ }^{282}$ one might conclude that California's overzealous extension of worldwide combination and the unitary business principle lies at the heart of the international business community's concern, ${ }^{283}$ and that there is nothing intrinsically wrong with applying the unitary concept globally. If it is the application of the unitary concept and worldwide combination to loosely connected far-flung enterprises that is creating the troublesome problems, then specific limitations on the states' powers to define businesses as unitary and to require worldwide combination would be more appropriate than the blanket prohibition on the states' use of worldwide combination embodied in H.R. 5076. For example, Congress might restrict the states' application of worldwide combination to corporations that are essential to each others' functions ${ }^{284}$ or that are operationally interdependent. ${ }^{285}$

Finally, on the continuing assumption that some congressional action is called for, the complex and interrelated problems associated with state taxation of interstate and foreign commerce demand a more comprehensive solution than the piecemeal approach embraced by H.R. 5076. The bill's narrowness can be explained in part by its history: it represents a congressional response to a similar but even narrower proposal incorporated in a United States - United Kingdom tax treaty. ${ }^{286}$ Nonetheless, by attacking only the issue of

281. House Foreign Source Income Hearing, supra note 4, at 5 (statement of Hon. Donald C. Lubick, Assistant Secretary of the Treasury for Tax Policy).

282. See, e.g., id. at 207-08 (statement of Roy A. Gentles, President, Alcan Aluminum Corp.); Interstate Taxation: Hearings on S. 2173 Before the Senate Comm on the Judiciary, 95th Cong., 1st \& 2d Sess. 498-502 (1977-1978) (statement of Mark G. Ancel); Tax Treaty Hearings, supra note 5, at 217-19 (statement of Valentine Brookes, Brookes \& Vogl, on behalf of EMI-Capitol Records, Inc.).

283. There are ongoing efforts in California to enact legislation limiting the state's use of worldwide combination. See Assembly Bill 525, reproduced and discussed in Senate Foreign Source Income Hearing, supra note 4, at 656-64.

284. See Skelly Oil Co. v. Commissioner of Taxation, 269 Minn. 351, 367-68, 131 N.W.2d 632,643 (1964).

285. See J. Hellerstein, Recent Developments in State Apportionment and the Circumscription of Unitary Business, 21 NATL. TAX J. 487, $501-03$ (1968).

286. Convention Between the Government of the United States of America and the Government of the United Kingdom of Great Britain and Northern Ireland for the Avoidance of Double Taxation and the Prevention of Fiscal Evasion with Respect to Taxes on Income and Capital Gains, 94th Cong., 2d Sess., art. 9(4) (1976); Protocol to the Convention, 94th Cong., 2d Sess. (1976); Second Protocol to the Convention, 95th Cong., 1st Sess. (1977), reprinted in 2 P-H Tax Treaties II $89,039,89,061,89,063$. The Senate withheld its consent from the portion of the treaty limiting state tax power in part on the ground that if such limitations should be effected at all, they should be effected through the traditional legislative process rather than by treaty. See House Foreign Source Income Hearing, supra note 4, at 289-90 (statement of John S. Nolan, Counsel, on behalf of the Confederation of British Industry and the British National 
state taxation of foreign source income insofar as it bears on worldwide combination and dividends, H.R. 5076 would give rise to a host of incongruous results and might create as many problems as it solves. For example, the bill would cause disparate treatment of corporate taxpayers depending on whether they operated abroad through branches or subsidiaries. ${ }^{287}$ The bill would also produce inconsistent treatment of dividends, for which there are special federal rules, and foreign source income from intangibles other than corporate stock, for which there are not. ${ }^{288}$ Especially in light of the GAO report and the increased attention being given state taxation of multistate and multinational business, ${ }^{289}$ Congress should approach whatever problems exist in this area by legislation more broadly conceived than H.R. 5076.

\section{B. H.R. 5076: Limiting State Taxation of Foreign Source Dividends}

In addition to prohibiting worldwide combination, H.R. 5076 restricts the states' power to impose corporate income taxes on foreign source dividends. ${ }^{290}$ In substance, the bill imposes upon the states the federal corporate income tax rules governing the taxation of such dividends. To evaluate the suitability of the federal model for purposes of state taxation, it will be useful to summarize that model.

To avoid double taxation of income at the corporate level, the federal tax laws generally permit corporations to deduct $85 \%$, or in some cases, $100 \%$ of the dividends received from other corporations to the extent that such dividends reflect income that has already been exposed to federal income taxation. ${ }^{291}$ This includes dividends

Committee of the International Chamber of Commerce). Thereafter bills were introduced in both the House and Senate proposing restraints on the states' power to tax foreign source income that included those sought by the treaty draftsmen. H.R. 5076, 96th Cong., 1st Sess. (1979); S. 1688, 96th Cong., 1st Sess. (1979); S. 983, 96th Cong., 1st Sess. (1979); see House Foreign Source Income Hearing, supra note 4, at 290 (statement of John S. Nolan, Counsel, on behalf of the Confederation of British Industry and the British National Committee of the International Chamber of Commerce). Efforts to limit worldwide combination by treaty are by no means dead, however. Treasury Secretary Miller and Canadian Finance Minister MacEachen agreed in late 1980 by an exchange of notes to reopen the dialogue to find a way to restrict the states' use of worldwide combination. 58 STATE AND LOCAL TAXES (All States Unit) (Report Bulletin) (P-H) If 18.1 (Oct. 28, 1980).

287. See Mobil Oil Corp. v. Commissioner of Taxes, 445 U.S. 425, 440-41 (1980).

288. 445 U.S. at 446.

289. See text at notes 1-8 supra.

290. H.R. 5076, 96th Cong., 1st Sess. § (a) (1979) (new I.R.C. § 7518(d)-(e)). See note 248 supra.

291. See I.R.C. $\$ \S 243-247,882$; B. BITTKER \& J. Eustice, FEDERAL InCOME TAXation of CoRPorations AND Shareholders If 5.06 (1979). When a group of affiliated corporations files a consolidated return pursuant to I.R.C. $\$ \S 1501-1505$, and the regulations there- 
received from domestic corporations operating abroad because domestic corporations are subject to federal income tax on their income from all sources. ${ }^{292}$ When the payor is a foreign corporation deriving its income from foreign sources, ${ }^{293}$ its dividends do not reflect income previously exposed to federal taxation. In this situation, there is no risk of double taxation under the federal corporate income tax, and no deduction for intercorporate dividends is permitted. Nevertheless, there may be a risk of international double taxation if the payor corporation has paid income tax to a foreign country on income distributed as dividends to a payee corporation subject to federal income taxation. To reduce this risk, the federal tax laws permit domestic corporations receiving dividends from foreign corporations in which they have a $10 \%$ ownership interest to claim a foreign tax credit for foreign income taxes paid by the foreign corporations. ${ }^{294}$

In accord with this scheme, H.R. 5076 imposes two separate limitations on the states' power to tax foreign source dividends, one applying to dividends received from domestic payors, the other to dividends received from foreign payors. First, the states are forbidden from taxing dividends received from domestic corporations earning less than $20 \%$ of their gross income from United States sources to the extent that such dividends qualify for the intercorporate dividend deduction under the federal tax laws. ${ }^{295}$ H.R. 5076 would thus permit states to include no more than $15 \%$ of such dividends in the payee's tax base and, depending on the degree of ownership of the payor by the payee corporation, it would in many cases deny them the right to take account of such dividends at all. $296 \mathrm{Sec}-$ ond, H.R. 5076 excludes from the state tax base of a payee corporation some or all of the dividends received from foreign corporations if they have been directly or indirectly subjected to foreign income

under, the effect is likewise to eliminate from the corporate income tax base any dividends paid by any member of the affiliated group to any other member of the group. Treas. Reg. $\$ 1.1502-14(a)(1)(1972)$. The statement in the text does not apply to dividend income of foreign corporations not connected with United States business, even though the dividends are received from sources within the United States. I.R.C. \$ 881. The federal tax on such income may, however, be reduced or eliminated by treaty. See I.R.C. $\$ 894$; B. BITTKER \& J. EUSTICE supra, at If 17.03 .

292. See I.R.C. $\S \S 11,61(a), 63(a)$.

293. See I.R.C. $\S \S 881-882$.

294. I.R.C. $\$ 902$.

295. H.R. 5076, 96th Cong., 1st Sess. § (a) (1979) (new I.R.C. § 7518(d)-e(1)(A)); see I.R.C. $\$ 861$ (a)(2)(A). H.R. 5076 also forbids the states from taking account of dividends eliminated from a corporation's federal tax base pursuant to the consolidated return provisions. See I.R.C. \$§ 1501-1505; note 291 supra.

296. See I.R.C. \& 243. 
taxes. The amount of the exclusion depends on the ratio of the foreign tax rate to the federal tax rate. ${ }^{297}$ If the rate at which the foreign income taxes paid or deemed paid 298 on the dividends received from a foreign corporation equals or exceeds the $46 \%$ federal tax rate, ${ }^{299}$ the dividends would be entirely excluded from the payee's state tax base. If the rate at which the taxes paid or deemed paid on such dividends is less than $46 \%$, the dividends would be taxable by the states only in proportion to the excess of the federal tax rate over the foreign tax rate. ${ }^{300}$ Inasmuch as most American corporations are subject to a greater than $46 \%$ foreign income tax rate on dividends received from foreign corporations in which they have at least a $10 \%$ ownership interest, ${ }^{301}$ the effect of H.R. 5076 would be to exempt from state taxation the lion's share of dividends that American corporations receive from foreign payors. ${ }^{302}$

It is apparent - if not from the above explanation, then from the proposal itself ${ }^{303}$ and the hearings addressed to it $^{304}$ - that there are interpretative and technical problems raised by H.R. 5076 that need to be explored in much greater depth than is feasible here before one can intelligently attempt to evaluate all of its ramifications. For present purposes, I shall limit my observations to the impact of H.R. 5076 on the result in Mobil and to the wisdom of the proposed legislation's overall design.

The enactment of H.R. 5076 would significantly affect the way Vermont, with the Supreme Court's approval, presently taxes the Mobil Oil Corporation. Although Vermont eschews worldwide combination ${ }^{305}$ and thus would be unaffected by the first limitation embodied in H.R. 5076, the restriction on state taxation of foreign source dividends would dramatically reduce Mobil's apportionable tax base for Vermont tax purposes. The vast preponderance of Mobil's foreign source dividends - some $90 \%$ or more - are received from foreign corporations in which Mobil has at least a $10 \%$ owner-

297. H.R. 5076, 96th Cong., 1st Sess. § (a) (1979) (new I.R.C. § 7518(e)(1)(B)-7518(e)(2)). 298. See I.R.C. $\$ \S 901-908$.

299. See I.R.C. $\S 11$. The marginal rate reaches $46 \%$ only after the surtax exemptions have been exhausted.

300. This proportion is determined by a complex statutory formula. See H.R. 5076, 96th Cong., Ist Sess. \& (a) (1979) (new I.R.C. \& 7518(e)(2)).

301. StafF of the Joint Comm. ON TAXation, Description of H.R. 5076 Relating to State Taxation of Foreign Source Corporate Income 19 (Joint Comm. Print 1980).

302. Id. at 19-20.

303. See note 248 supra.

304. See House Foreign Source Income Hearing, supra note 4, passim; Senate Foreign Source Income Hearing, supra note 4, passim.

305. See text following note 60 supra. 
ship interest. ${ }^{306}$ On the reasonable assumption that Mobil pays or is deemed to pay foreign income taxes on such dividends at rates comparable to $46 \%,{ }^{307}$ all such dividends would be excluded from Mobil's apportionable tax base in Vermont. As to Mobil's foreign source dividends from domestic corporations, H.R. 5076 would leave Vermont's present taxing scheme intact. Because Vermont conforms to the federal corporate income tax rules regarding the deduction for intercorporate dividends, ${ }^{308}$ the State is now taking account of foreign source dividends from domestic corporations in precisely the manner that H.R. 5076 permits. ${ }^{309}$

The impact of H.R. 5076 on other states would depend on how they treat foreign source dividends for corporate income tax purposes. The states treat such dividends in a variety of ways. ${ }^{310}$ For example, there are substantial variations in the extent to which the states follow the federal rules governing the intercorporate dividend deduction, ${ }^{311}$ and some states do not tax foreign source dividends at all. ${ }^{312}$ However, since thirty-eight of the forty-five states with corporate income taxes do tax foreign source dividends, ${ }^{313}$ and the state revenue produced is in the billions of dollars, ${ }^{314}$ H.R. 5076 would have a major impact on state taxation.

The question remains whether these constraints are warranted. In striking contrast to the multifaceted and anguished pleas for legislative relief from burdens of worldwide combination, the case for restricting state taxation of foreign source dividends is more limited and restrained. ${ }^{315}$ The two principal reasons advanced for confining

306. Appendix to the Court's opinion at A75-76, Mobil Oil Corp. v. Commissioner of Taxes, 445 U.S. 425 (1980).

307. See text at note 301 supra.

308. VT. Stat. ANN. tit. 32, $\S \$ 5811(18), 5832$ (Supp. 1979).

309. The importance of this source of Mobil's income has been substantially reduced by its sale of its $10 \%$ interest in the Arab American Oil Company, which was responsible for nearly all of Mobil's foreign source dividends from domestic corporations. Appendix to the Court's opinion at A76, Mobil Oil Corp. v. Commissioner of Taxes, 445 U.S. 425 (1980).

310. See House Foreign Source Income Hearing, supra note 4, at 357 (statement of Allen R. Voss, Director, U.S. General Accounting Office).

311. For example, whereas Vermont adopts the federal rules, see note 308 supra, California generally permits a deduction only for dividends from income already taxed by California, CAL. Rev. \& TAX CODE $\$ 24402$ (West 1979), and Kentucky does not include dividends in the tax base at all. KY. Rev. STAT. ANN. $§ 141.010(12)(b)$ (Bobbs-Merrill 1970).

312. See note 310 supra.

313. Id.

314. It has been estimated that foreign source dividends in the amounts of $\$ 2.2$ billion from subsidiaries and $\$ 520$ million from nonsubsidiaries were included in the states' tax base in 1972. Carlson, State Taxation of Corporate Income from Foreign Sources, in EsSAYS IN INTERNATIONAL TAXATION: 1976, at 231, 266 (U.S. Dept. of Treasury).

315. Indeed, many of the witnesses testifying in support of H.R. 5076 failed to mention the 
the states' power are, first, that the states have not contributed to the production of the income underlying the dividends and therefore are not justified in taxing them, ${ }^{316}$ and, second, that permitting the states to tax such dividends beyond the extent to which the dividends are subjected to federal income taxation violates federal policy against international double taxation. ${ }^{317}$ The first proposition is a non sequitur and the second is predicated on a spurious analogy between the federal and state tax systems.

There is no legal foundation for the contention that a jurisdiction's right to tax dividends received by a payee depends on the connection of the jurisdiction to the production of the income underlying the dividend. Dividend income and operating income have traditionally been treated as distinct items of taxable income, ${ }^{318}$ and the power to tax the latter has never been a constitutional predicate of the power to tax the former. ${ }^{319}$. Indeed, in pressing its claim before the Supreme Court that Vermont lacked the power to tax its foreign source dividends, Mobil did not rely on the broad proposition now urged by proponents of H.R. 5076. Rather, Mobil relied on the narrower proposition that Vermont lacked the power because it was not the state of Mobil's commercial domicile.320 Mobil conceded that New York had the power to tax its dividends without regard to New York's relationship to the operating income underlying the dividends. Dividend income has traditionally been attributed to states for income tax purposes based on commercial domicile, business situs ${ }^{321}$ and other theories, without regard to operating income.

Needless to say, Congress is not bound to traditional legal doctrine if sound policy dictates otherwise. And there may well be sound policy reasons, as Mobil unsuccessfully argued to the

foreign source dividend limitations altogether. See, e.g., House Foreign Source Income Hearing, supra note 4, at 209-13 (statement of Robert E. Dillon, Jr., Senior Vice President, Finance, Sony Corporation of America).

316. See, e.g. id. at 162 (statement of Ernest S. Christian, Jr., Counsel, Committee on State Taxation of the Council of State Chambers of Commerce).

317. See, e.g., id. at 150 (statement of Charles W. Wheeler, Senior Tax Attorney, Chamber of Commerce of the United States).

318. See, e.g., 2 S. Surrey, W. Warren, P. McDaniel \& H. Ault, Federal Income TAXATION 168 (1980).

319. See Rottschaefer, State Jurisdiction of Income for Tax Purposes, 44 HaRv. L. REv. 1075, 1094-95 (1931).

320. See text at notes 105-08 supra.

321. Under the business situs doctrine, intangibles "may acquire a situs for taxation other than that of the owner if they have become integral parts of some local business." Farmers Loan \& Trust Co. v. Minnesota, 280 U.S. 204, 213 (1930). See J. Hellerstein \& W. HellerSTEIN, supra note 16, at 441-42. 
Supreme Court, for allocating all of the corporation's dividends to the state of the corporation's commercial domicile rather than apportioning the dividends among the different states where the corporation carries on various operating activities. ${ }^{322}$ Moreover, if dividends are apportioned among the states, there are strong arguments for requiring a state that is empowered to tax an apportioned share of a corporation's dividends to adjust its apportionment formula to reflect the fact that it is taxing dividends and not operating income. ${ }^{323}$ But H.R. 5076, consistently with the rationale offered by its supporters, goes far beyond such measures. It excludes a substantial portion of a corporation's foreign source dividends from any state tax base, and would thus prevent New York as well as Vermont from taxing almost all foreign source dividends that Mobil receives. ${ }^{324}$ This limitation is contrary to tradition and precedent as well as federal tax policy, which is generally to tax all dividends from whatever source derived. ${ }^{325}$

The second justification advanced for H.R. 5076's limitation on state taxation of foreign source dividends is that it is necessary to carry out established federal policy against international double taxation. The thesis is that the states violate the policy when they tax foreign source dividends to a greater extent than the federal government, and the appropriate remedy is to impose upon the states existing federal limitations on the effective taxation of such dividends. ${ }^{326}$ The premise underlying this argument is that the problems of international double taxation at the national level are the same as the problems of international double taxation at the state level. Because this premise is false, legislation predicated on it is seriously flawed.

The problem of international double taxation arises at the national level because the federal government has the power to tax a domestic corporation's entire global income. As a result, the federal

322. A corporation's commercial domicile might be selected as the state with sole authority to tax the corporation's dividends to assure uniformity of treatment that may not be achieved through apportionment, or because the state of commercial domicile enjoys a more direct relationship with those dividends than do other states in which the corporation would otherwise be taxable.

323. See text at notes $85-92$ supra.

324. See text at notes 297-302 \& 305-07 supra.

325. See I.R.C. $\$ \S 11,61(\mathrm{a})(7), 63(\mathrm{a})$. While the federal tax code ultimately modifies its sweeping stance toward inclusion of dividends in the tax base to minimize double federal taxation of corporate income and international double taxation of income, see I.R.C. $\$ \& 243$, 901-908, these considerations should in fact have little bearing on state tax policy for the reasons discussed immediately below.

326. See text at notes 291-300 supra. 
government may tax income that has its source in a foreign jurisdiction and that is taxed by the foreign jurisdiction. The two federal income tax devices noted earlier - the intercorporate dividend deduction where the payor is a domestic corporation, ${ }^{327}$ and the foreign tax credit where the payor is a foreign corporation ${ }^{328}$ - are necessary to prevent such duplicative taxation of foreign source dividends.

The problem of international double taxation that exists at the national level cannot, at least in principle, arise at the state level because the states, unlike the federal government, generally lack the power to tax domestic corporations on their global income. State power to tax multijurisdictional corporations has always been constrained by the commerce and due process clauses. ${ }^{329}$ These constitutional strictures forbid the states from taxing any income including foreign source dividends ${ }^{330}$ - that is not fairly attributable to activities carried on within their borders. To be sure, the reality may not perfectly fit the theory. The various division-of-income methods actually chosen by the states under the constitutional mandate to tax only a fair share of a corporation's income may be inconsistent with methods employed by other jurisdictions to divide such income, ${ }^{331}$ with resulting double taxation. And federal legislation designed to deal with this problem may well be appropriate. ${ }^{332}$

But H.R. 5076 does not respond to this problem. Rather, it responds to the problem of international double taxation at the state level on the false assumption that it is identical to the problems at the national level. And the results are analytically indefensible. Thus H.R. 5076 imposes the federal intercorporate dividend deduction rule upon the states with respect to dividends received from domestic corporations whose income is largely from foreign sources. This rule was designed to deal with the problem of double taxation of corporate income by the federal government itself, ${ }^{333}$ though it may incidentally solve the problem of international double taxation

327. I.R.C. \$ 243; see text at notes 291-92 supra.

328. I.R.C. $\S \S 901-908$; see text at notes 293-94 supra.

329. See text at notes 34-39 supra.

330. Mobil Oil Corp. v. Commissioner of Taxes, 445 U.S. 425 (1980).

331. See text at notes 109-29 supra; cf. Japan Line, Ltd. v. County of Los Angeles, 441 U.S. 434 (1979) (property taxation case holding that even properly apportioned state property taxation of instrumentalities used in foreign commerce can create an impermissible risk of multiple taxation when the instrumentalities are also taxed by a foreign jurisdiction) (discussed in text at notes 143-55 supra).

332. See, e.g., text at notes 85-96 supra.

333. See Schaffer, The Income Tax on Intercorporate Dividends, 33 TAX LAw. 161, 162 (1979). 
at the national level.334 At the state level it deals with neither problem satisfactorily. If one wished to solve at the state level the problem that is equivalent to double taxation of corporate income by the federal government, one would only forbid a state from taxing dividends arising out of income that the state has already taxed as income to the payor corporation. Indeed, a number of states, although not Vermont, have adopted such an approach to the taxation of corporate dividends. ${ }^{335}$

Moreover, H.R. 5076 is unresponsive to the issue of international double taxation at the state level. If a state is apportioning income, including foreign source dividends, by a formula that accurately reflects the sources underlying that income (which is presumably the method that states will be required to follow after Mobil ${ }^{336}$ ), limiting the state's tax base to a maximum of $15 \%$ of such dividends is unwarranted. The federal limitation may in some rough sense be a justifiable antidote to the apportionment of dividends by a formula that failed to reflect their contribution to a taxpayer's income. (Such an apportionment was sustained by the Supreme Court in Mobil . ${ }^{337}$ ) If, however, one believes that the Court will ultimately require a fair apportionment of such dividends, as I do, then there is no warrant for excluding the foreign source dividends from the taxpayer's apportionable tax base.

Nor can the limitation on state taxation of foreign source dividends received from foreign corporations be defended as a matter of sound tax policy. As noted above, ${ }^{338}$ H.R. 5076 prohibits the state taxation of such dividends if the foreign taxes borne by the dividends (or the income underlying them) give rise to a federal foreign tax credit. But the federal foreign tax credit is designed to avoid duplicative taxation at the national level of earnings derived from sources outside the United States. ${ }^{339}$ It has - or should have - no bearing on the power of a state to tax such income. State income taxes have always been imposed in addition to federal income taxes. Indeed, as the Supreme Court noted in Mobil, "[c]oncurrent federal and state taxation of income, of course, is a well-established norm."340 While

334. See text at notes $291-92$ \& 327 supra.

335. See, e.g., CAL. Rev. \& TAX Code $\$ 24402$ (West 1979).

336. See text at notes 82-104 supra.

337. See text following note 64 supra.

338. See text at notes 297-300 supra.

339. See, e.g., D. Tillinghast, TAX Aspects of International Transactions $\$ 2.1$ at 35-37 (1978).

340. Mobil Oil Corp. v. Commissioner of Taxes, 445 U.S. 425, 448 (1980). 
stated as a principle of constitutional adjudication, the statement is relevant as well to federal policy toward state taxation. Federal policy should be sensitive to the existence of the independent taxing powers of the states out of respect for the independent role of the states in our federal system. By contrast, H.R. 5076 restrains state taxing authority over foreign source dividends without regard to the relationship of the state to those dividends, thus ignoring the predicate on which state tax authority is based. Furthermore, under H.R. 5076 state tax power over foreign source dividends would expand or contract depending on the foreign tax rate to which such dividends or the income underlying them had been exposed, a factor that is extraneous to whether a state is taxing its fair share of such dividends. In short, while the problems raised by state taxation of foreign source dividends may warrant federal legislative intervention, ${ }^{341}$ they do not warrant limitations like those embodied in H.R. 5076. The relief from international double taxation that the federal government provides to domestic corporations - all of whose income is subject to federal taxation - when some of their income is also subject to foreign taxation, carries with it no implied prescription for relief from state taxation, which is limited to income fairly attributable to the state and has always coexisted with taxation at the national level.

In summary, H.R. 5076 is an overreaction to the problem of state taxation of multinational corporations. First, the bill responds to the Court's failure to delimit the constitutional contours of a unitary business by effectively prohibiting application of the unitary business principle to international multicorporate enterprises, rather than by defining statutory limits that would prevent overzealous state taxation of loosely connected corporations. It confines the application of the unitary business principle by imposing the federal tax scheme on the states. Yet imposing the federal approach may be inconsistent with principles of federalism and may create incongruous results and problems of its own. Second, H.R. 5076 deals with the difficulties that may be involved in establishing constitutional standards to ensure the fairness of apportionment formulas applied to foreign source dividends by simply exempting most foreign source dividends from state taxation, rather than by imposing statutory requirements of fairness. It would accomplish this by again imposing the federal tax model on the states. Such a limitation misconceives the problem

341. See text at notes 331-32 supra. 
of international double taxation at the state level and is, once again, inconsistent with principles of federalism.

\section{CONCLUSION}

In Mobil and Exxon, state taxing authorities took on two of the nation's three largest industrial corporations $\mathrm{s}^{342}$ and emerged from the judicial arena with resounding victories. The Supreme Court emphatically reaffirmed the states' broad power to tax multistate and multinational business and stressed its own limited role in keeping these powers within constitutional bounds. The Court repeated its standing invitation to Congress to legislate in the state tax field if it is unhappy with the results of the Court's decisions. ${ }^{343}$ Perhaps this time Congress will accept that invitation and dramatically reshape the restraints on state taxation of multijurisdictional enterprise. Should Congress be so inclined, it should fashion a solution more responsive than H.R. 5076 to the problems it perceives; a solution that, unlike H.R. 5076, does not needlessly trench on the states' taxing authority.

342. See notes 32 \& 165 supra.

343. Mobil Oil Corp. v. Commissioner of Taxes, 445 U.S. 425, 449 (1980). 